\title{
The Gravity of Arms
}

\begin{abstract}
The aim of this paper is to investigate the determinants of international arms transfers in a gravity model framework. By distinguishing between the decision to export arms (extensive margin) and the value of the arms exported (intensive margin), while also considering its interdependence, is what differentiates this paper from previous research. A theoretically-justified gravity model of trade augmented with political and security motives is estimated using a two-stage panel data approach for 104 exporting countries over the period from 1950 to 2007 . In addition to the usual gravity variables related to the economic mass of the trading countries and the trade cost factors, the model is extended with political and security factors. The level of democracy in both trading partners, political differences between trading partners and voting similarity with the United States in the UN General Assembly of the countries engaged in trade are the main political factors, whereas the existence of conflicts, military pacts and embargoes are taken as security motives. The key result indicates that both political and security motives are an important determinant of an arms trade, but their effects on the extensive margin of exports (the decision to order a transfer) differs from their effect on the intensive margin (average value of exports). Moreover, the relative importance of the factors under study has changed since 1989. In the post-Cold War period, countries that are less democratic are more likely to export arms, military pacts are less relevant and embargoes play a role.
\end{abstract}

\section{JEL classification: F14, F51}

Key Words: arms trade, political factors, margins of trade, gravity model, two-stage approach 


\section{The Gravity of Arms}

\section{Introduction}

Several recent research papers have stressed the importance of analyzing the determinants of international trade at the industry level to account for industry-specific economic and political factors (Head and Mayer, 2014). The armament industry has usually seen as particularly different from other industries (Kinsella, 1998; Blanton, 2000) regarding the role played by the political environment and the geopolitics of transfers in the decision to export (Catrina, 1998; Krause, 1991, 1992; Anderton, 1995). Many developing countries have been increasing their capacity to produce arms and some are trying to establish a domestic military industry to be less dependent on imported arms (Brauer 2000; Blanton, 2005). However, these countries have yet to become successful exporters of arms on a larger scale (Brauer 2007). Meanwhile, the supply of military goods is very concentrated on a global scale ${ }^{1}$, with ten exporters covering more than ninety percent of the world market (Stockholm International Peace Research Institute, SIPRI) for the period from 1950 to 2007, and thus investigating the main motives that explain the international arms trade remains an important issue (Fleurant et al, 2017).

Understanding how different factors, namely economic and political motives, affect the decision to export arms is crucial in providing a scientific basis for the public debate on the regulation of trade concerning major conventional weapons (MCW). Furthermore, strategic and security motives that could be the main drivers of demand constraints in the arms trade, are also a relevant focus of study. Such factors include conflicts, the degree of militarization of the society in question, the existence of military alliances and the effectiveness of embargoes.

The importance of the political environment in the transfer decision, has been widely investigated in the political science literature (Krause, 1991, 1992; Blanton, 2000, 2005; Catrina, 1988; among others), but scarcely so in the economic literature (as noted by Anderton, 1995). The richness of the data available is suitable to apply a gravity model of trade to empirically investigate the drivers of the supply and demand factors, as well as to distinguish between the economic, political, strategic and security motives, of arms transfers. To the best of our knowledge, there are only two economic

\footnotetext{
1This is commonly attributed to countries reacting against "military Malthusianism", according to which unit costs of major weapon systems rise faster than government budget revenues. As a reaction, countries might try to reduce the unit costs by increasing exports and profiting from economies of scale to counteract the increasing costs of domestic production (Brauer and Dunne, 2011).
} 
studies (Akerman and Seim, 2014 and Comola, 2012) that have made some progress in this direction.

The main aim of this paper is to investigate the determinants of the arms trade under the framework of the gravity model of trade, including several economic, political and security factors that affect the decision to export arms and the value of a trade deal by using a two-stage model suitable for analyzing the decision-making process. As key political factors, we consider the level of democracy in the trading partners as well as the political orientation of the ruling governments, the political differences between trading partners and their voting similarities. The security factors are conflicts, established military and strategic pacts and embargoes. To our knowledge, this is the first study that consistently examines the determinants of the extensive and intensive margins of the international arms trade using up-to-date panel data econometric models and a comprehensive sample of countries and years.

The main contribution of this paper, with respect to previous studies, is that we base our empirical strategy on the new developments in the theory of international trade (Melitz, 2003; Helpman et al, 2008) and distinguish between the determinants of the decision to export (extensive margin of exports) and the determinants of the amount exported (intensive margin of exports). Moreover, we focus not only on the level of democracy as Akerman \& Seim (2014) do, but also on the political orientation of the ruling governments as well as on the political similarities between trading partners. Whereas Comola (2012) used a categorical variable with only three dimensions ${ }^{2}$, limited time coverage and country-time variation to measure political orientation, we use a measure based on a country's voting behavior in the United Nations General Assembly (UNGA), which has more variability and more extensive time coverage.

Since both the decision to export arms and the amount exported may be related, we use a two-stage estimation procedure to control for selection bias (similar to Blanton, 2005) while also controlling for firm heterogeneity (Helpman et al. 2008), which indicates that only a few firms are able to cover the fixed costs of exporting that is necessary to become an exporter while other firms produce for the local market. We also control for time-invariant unobservable heterogeneity by using wellestablished econometric techniques (Baltagi and Egger, 2014).

Our estimation framework is based on a theoretically justified gravity model of trade (Anderson and van Wincoop, 2003; Helpman et al., 2008), which is applied to data for 104 exporters over the period from 1950 to 2007 . To test for the robustness of the results, we estimate the model using

\footnotetext{
${ }^{2}$ The tree dimensions are right, center and left oriented governments from the World Bank Development Research Group's Database of Political Institutions.
} 
several variations of our dataset and estimation techniques. Furthermore, we compare the determinants of the arms trade with those of trade in other goods and evaluate differences in the impact of the different dimensions considered, namely the economic, political and security factors.

The main results show that the selected factors are relevant in explaining the two types of trade margins of the arms trade, but the effects differ for each trade margin. The end of the Cold War appears to have changed the impact of several political factors, especially those measuring the political and security factors. However, differences in political orientation continue to have a significant negative impact on two countries' probability of transferring arms in the $2000 \mathrm{~s}$.

The rest of the paper is structured as follows. Section 2 summarizes the related literature in this field and presents the theoretical framework. Section 3 gives an overview of the data and variables used and the main stylized facts. Section 4 presents the specification of the empirical models and Section 5 outlines and discusses the main results. Finally, Section 6 concludes.

\section{Literature Review and Theoretical Framework}

\subsection{Related theories and empirical literature}

The existent literature concerning arms transfers is wide in the field of political science, starting with the classical works by Krause (1991, 1992), Laurance (1992) and Catrina (1988, 1994). Whereas Krause (1991) refers to the three dimensions of influence that relate to arms transfers, namely, bargaining power, structural power and hegemonic power, Krause (1992) and Laurence (1992) provide the framework for analysis of the different phases of arms trade history. Catrina (1994) focuses instead on the description of the different stages involved in arms transfers as well as the parties involved, their interest and all of the legal aspects related to it. Moreover, he identifies several relevant research questions, among them the need to use quantitative information to identify the general trends, the determinants and the mechanisms of arm transfers.

To approve an international shipment of arms, the countries involved must first evaluate if the associated benefits outweigh the risks and costs attached to the trade deal. The gains for the exporting country include revenues for the domestic industry in the related sectors and in turn job protection in these sectors, while the costs are mainly related to political, economic and strategic/security factors (Brauer, 2000 and 2007; Blanton, 2005). Moreover, exporting should also generate increasing economies of scale in production, resulting in lower costs and enhanced international competitiveness of the firms involved (Anderton, 1995). These gains, however, can be offset by potential negative effects, which are linked to the fact that the exporting country loses 
control over the arms once they are exported and this increase insecurity. Thus, these arms could eventually be used against the exporter or its allies and so the delivery of these tools of destruction can be problematic from a strategic and security standpoint. In addition, there is potential for copyright infringements and there may be negative reactions and pressure from third countries as a response to weapon exports. Democratic countries may see a strong, negative public reaction to their exports, especially if arms are exported to non-democratic authoritarian countries.

From the point of view of the trade partners, the arms trade can establish or strengthen a given bilateral relationship. It can also lead to a transfer of knowledge $\mathrm{e}^{3}$ or possibly attempt to influence the importer's policies ${ }^{4}$ and could fuel an arms race in the region of the importer. All of these effects have different implications for the potential trading partners depending on the conditions of the contract.

The dependence theories in the political science literature (Catrina, 1988) state that arms trade might generate dependent relationships between suppliers and consumers. Catrina (1988) concludes that albeit being a contributing factor, arms transactions generate less dependence today than in the past and there are other factors that are more likely to generate dependence such as economic vulnerability or political stability. In this sense, it is crucial to consider political factors, such as the level of democracy or the political orientation, as explanatory factors of arms trade.

In addition to the mostly self-serving reasons described above, the arms trade can also be the result of altruistic behavior, with the aim of helping the receiving country to maintain or re-establish safety and security (Akerman \& Seim 2014). The potential positive and negative effects described above create uncertainty on the real outcomes in several different aspects related to the shipment of arms. The political orientation in a recipient country can be an indicator of the level of uncertainty, as can the political differences between a supplier and recipient. Indeed, some authors find that countries may discriminate against certain political regimes when exporting arms. In particular, Blanton $(2000,2005)$ finds that the United States largely exports arms to democratic countries, especially in the post-Cold War period. This could be due either to support for countries that are in close political alignment with the United States, or to the fact that the United States expects negative externalities to be minimized when exporting to democratic countries. This will be in accordance with the "liberal peace" or "democratic peace" hypothesis stating that democracies are less likely to be engaged in armed conflict with each other (Chan, 1997).

3 According to Brauer \& Dunne (2009), the knowledge transfer of offset agreements is, if it exists at all, relatively small.

4 Investigating United States arms exports, Sislin (1994) finds successful attempts to influence the partner countries under certain conditions, especially in the first decades of the Cold War. 
Anderton (1995) states that there is little theoretical and empirical development of the economics of arms transfers, with a few exceptions such as Levine, Sen and Smith (1994), Levine and Smith (1997) and Smith and Tasiran (2005). Most models are based on strategic behavior and/or demand and supply functions and their estimates. Anderton (1995) refers to the traditional and neoclassical international trade theories to explain the international demand and supply of weapons, and refers to the general equilibrium nature of arms trade highlighted by the neoclassical models, which predict that countries will specialize in the production and export of goods that intensively use the resources that are relatively abundant in a respective country. Accordingly, if arms production, and especially MCWs, uses capital intensively, the theory predicts that countries with a higher capital to labor ratio will have a comparative advantage in exporting arms. In addition, according to the new trade theories based on economies of scale and imperfect competition, we could assume that major weapons production is subject to economies of scale and hence countries will tend to specialize in the production and export a narrow range of products to exploit these economies of scale.

Finally, and not mentioned by Anderton (1995), we should refer to the new-new trade theories of trade that rely on heterogeneity in productivity among firms and predict the existence of zero trade flows in international trade, since only very few productive firms are able to cover the fix costs of exporting (Helpman, Melitz and Rubinstein, 2008). A model that can be derived from all of these trade theories, and that has been labelled as the "workhorse" of empirical trade analysis, is the gravity model of trade (Feenstra, 2015; Anderson and van Wincoop, 2003). It has been extensively used to explain the determinants of aggregate and disaggregated bilateral trade flows and it is also suitable to explain bilateral arms transfers.

To the best of our knowledge, there are only two studies using the gravity model of trade to explain arms transfers. Both studies use the same dataset on arms transfers and emphasize changes after the end of the Cold War. These studies differ in their political aspects and the time periods covered, their econometric approach and their main results. On the one hand, Akerman \& Seim (2014) investigate the impact of the level of democracy on the probability of trading arms for many countries $^{5}$ over the years 1962-2000, using a linear probability model with exporter and importer dummy variables that are used as proxies for unobserved factors that are country specific and time invariant. They find that the squared difference in polity (a proxy for democracy) between trading partners has a large and significant negative impact on the target variable, but that the effect

\footnotetext{
${ }^{5}$ The list of exporters and importers included in the estimations is not provided by Akerman and Seim (2014). The indicated number of observations included in Table 1 (page 541) is more than 600 thousand in the models with country fixed effects, shown in columns (3) to (6), but only around 300 thousand in the models without country fixed effects, columns (1) to (3), the authors do not explain this discrepancy.
} 
becomes positive and non-significant after the end of the Cold War. The main shortcoming of this study is that they do not include security factors in their econometric model (embargos, pacts, conflicts) and in the network analysis they only consider trade among 34 countries (members of NATO plus members of the Warsaw Pact). Moreover, the only political factor considered is the difference in the levels of democracy between trading countries. A second limitation is that they focus only on the decision to trade arms, and thus fail to account for the effect on the traded value. A final limitation is the use of a linear probability model, since the residuals violate assumptions on homoskedasticity and the normality of errors and this invalidates the standard errors and tests.

On the other hand, Comola (2012) extends the analysis by using the political orientation of the trading countries as a second political dimension, but fails to distinguish between the factors that affect the decision to export and those that affect the value of the transfer. She investigates the effect of two political dimensions, namely democracy and political orientation, on the volume of arms exported from the 20 major exporters to all independent countries recognized by the United Nations in the period 1975-2004. The estimation method is a gravity-type Tobit model with exporter, importer and time dummy variables. The main findings are that democracies tend to export and import higher amounts of arms than autocracies and that while democracies export them mostly to rich countries, autocracies tend to export to poor countries. Furthermore, sharing a political orientation has a positive impact on trade that sharply decreases after the end of the Cold War, especially for democracies. It is worth noting that the measure of political orientation used by Comola (2012), which is constructed using the World Bank Development Research Group's Database of Political Institutions, has several shortcomings. First, it only covers the period after 1974 and in many cases, has no information on the political orientation of the ruling party, resulting in many gaps in the dataset. Second, the variable is a subjective measure, which is not strictly comparable between countries and identifies only three categories that cannot capture smaller differences in political orientation. Third, it focuses on economic policy rather than on foreign policy and has no variation over time for communist countries, while capitalist or market liberal countries have governments from all three categories.

Both studies find that political determinants are important in terms of explaining the international flows of major conventional weapons (MCWs) and describe a decrease in the importance of political differences between a supplier and recipient after the end of the Cold War. However, both studies fail to acknowledge the recent advances in panel data gravity models that allow the extensive and the intensive margin of trade to be distinguished between and to account for the fact that both are interdependent. A two-stage model in the spirit of Helpman et al. (2008) allows for 
this distinction and for the evaluation of the decision-making process (as proposed by Blanton, 2005). The first stage addresses whether an economy is eligible to receive MCWs, whereas the second stage is based on the decision of the amount of arms transferred. Only the countries that successfully pass the selection stage are eligible as recipients of MCWs.

We will extend these studies by using a more comprehensive dataset that includes all exporters ${ }^{6}$ and importers trading arms, an extended set of policy variables and security and strategic factors (embargoes and pacts), as well as a more suitable estimation technique that allows us to distinguish between the effect on the extensive and intensive margins of the arms trade. Indeed, we can distinguish between economic, security (defense pacts and embargoes) and political motives.

An additional issue that has special interest for arms trade is the evolution over time of trade restrictions on MCWs, which has been covered by Levine and Smith (1997) and more extensively by Bromley et al. (2012). International trade in MCWs has been generally controlled by national governments. The corresponding authorities in each country select the potential buyers based on judgments concerning the intentions of how the weapons will be used. There have always been several multilateral controls; the most extensive agreement signed in the past was the Coordinating Committee for Multilateral Export Controls (COCOM), which was established in 1949 by western countries to stop the Soviet Union and its satellite countries from buying weapons and technologies from western producers. It lasted until 1994 and was replaced two years later with the Wassenaar Arrangement on Export Controls for Conventional Arms and Dual-Use Goods and Technologies (WAECC). The main difference with the COCOM is that the WAECC covers 41 States, including Russia and other COCOM countries ${ }^{7}$, with its main aim to contribute to regional and international security and stability.

More recently, after many years of difficult negotiations, the landmark Arms Trade Treaty (ATT), regulating the international trade in conventional arms and including small arms, entered into force in December 2014. With 90 state parties, 88 ratifying countries and 130 signatory countries, it is the most comprehensive treaty ever signed. It requires state parties to establish and maintain export control systems that are transparent and comply with the provisions and enforcement of relevant prohibitions of the ATT. Given that the ATT has only been in force for a few years, it is outside the scope of this paper to evaluate the effectiveness of the treaty.

\footnotetext{
${ }^{6}$ Blanton (2005) focused on United States exports exclusively.

${ }^{7}$ List of participants: Argentina, Australia, Austria, Belgium, Bulgaria, Canada, Croatia, Czech Republic, Denmark, Estonia, Finland, France, Germany, Greece, Hungary, Ireland, Italy, Japan, Latvia, Lithuania, Luxembourg, Malta, Mexico, Netherlands, New Zealand, Norway, Poland, Portugal, Republic of Korea, Romania, Russian Federation, Slovakia, Slovenia, South Africa, Spain, Sweden, Switzerland, Turkey, Ukraine, United Kingdom and United States.
} 
Meanwhile, single countries have their own control regimes, but the information about the way controls are established is not always transparent and differs greatly across countries. Given the lack of available information for all countries and over time for specific controls, we are not able to directly consider them in the regression analysis. We could only assume that they are country specific and vary slowly over time and try to model them with country specific dummy variables.

\subsection{Theoretical framework}

In this subsection, we develop the theoretical arguments that provide a rationale for the consideration not only of economic factors, but also of political and security factors in creating frictions/enhancers to trade in MCWs. We discuss the political and security motives and incorporate those in the framework of the international trade literature.

The case of the arms trade is particularly different from trade in other goods. The demand for arms is mainly related to security concerns for internal, as well as external threats, for having to engage in a conflict (Levine and Smith, 1997). Arms demand is also used as a preventive measure to emit a general posture of power. However, this could generate insecurity in other countries. For this reason, minimizing the existence of arms should be the optimal outcome for maximizing the utility of the world economy. Consumers in a given country would therefore prefer a reduced supply of MCWs at a higher cost, so that it is difficult for other countries to compete in the industry and to generate insecurity for the larger producers. As a consequence, the forces of the market result in the existence of a few suppliers with a small number of large firms exporting MCWs and operating in imperfect competition. The exporters, which are mostly global dominant players, would prefer not to export large quantities to any of the recipients in order to maintain its dominant power.

National security concerns could be influenced by the formation of pacts or alliances. In fact, the risk of not having arms is reduced by being part of an alliance, ${ }^{8}$ which in turn implies a cumulative value of regional security. Thus, national security will be a function of domestic and regional security, and the weight that regional security will play will depend on the "dominant role" of an exporter.

According to the international trade literature, higher bilateral trade volumes between countries are a direct consequence of higher incomes in the trading economies, lower trade barriers between them and a greater proportion of exporters (Helpman et al., 2008). The gravity model of trade indicates that some trade frictions would have an influence on the fixed cost of exporting, whereas others would mainly affect the variable cost and hence, the export volume, once the exporting decision has

\footnotetext{
${ }^{8}$ Military pacts can be classified as defence, nonaggression, entente and neutrality pacts.
} 
been made. The level of income in a supplier country indicates the production capacity of the country, whereas the income in a recipient country indicates the market size of the buying economy. On the other hand, income per capita could be a proxy for the relative factor endowments of the supplier, with rich countries tending to be capital abundant in relative terms. The level of income per capita in a recipient country could indicate the type of good that the country could be able to buy, with rich countries being able to buy -more expensive- higher quality goods.

With respect to trade frictions (facilitators), it is expected that the classical proxy for trade cost, the distance between countries, decreases the likelihood that two countries will trade, but could also affect the exported value, whereas other factors such as common language, common borders would mainly affect the fixed cost of exporting. The effect of distance on the value exported could also be positive assuming that countries send higher average quantities to countries far away, so that in case the recipients would use the weapons, the supplier is far from the potential user of the weapons.

Intending to use the gravity model to explain trade in MCWs implies that we must consider specific factors that are especially relevant for this industry. According to Levine and Smith (1997) concerns about internal stability, regional hostility, general insurance and demonstration of power determine the need for arms.

Hence, we extend the typical gravity model of trade with several factors used as proxies for the abovementioned factors. First, we test not only for the importance of the level of democracy in a supplier and recipient of arms, which serve as a proxy for internal stability, but also the difference between them to test for the democratic peace hypothesis.

Second, knowing that staying in power is one of the objectives of the dominant MCWs exporter, the United States, we use the voting similarity between the United States and the exporter and the United States and the importer as proxies for the affinity between the superpower and the rest of the potential suppliers and recipient of arms. We expect that voting similarity is a proxy for political affinity and orientation and hence a higher level of voting discrepancy with the United States is expected to be positively related with arms trade in the supply side and negatively related in the demand side. In particular, it is expected that arms transfers to a given destination increase when there are cordial diplomatic relations between the United States and the destination countries. In addition, the voting similarity between the trading partners is also added as a proxy of political affinity between them, which is expected to be positively related to arms trade.

Finally, the gravity model is also augmented with the level of militarization in the economy, which is a proxy of the desire to project power internationally. Militarization can affect the supply and 
demand of arms through various channels (Smith and Tasiran, 2005, 2010). A higher degree of militarization and in turn a higher domestic demand for arms is expected to strengthen a domestic arms industry and hence could foster exports. But since the domestic production of arms and equipment is usually preferred to foreign production, for strategic reasons, a higher militarization could also be related to lower exports if the domestic demand increases and foreign demand decreases, as happened in the post-Cold War period. This is especially true when domestic production can satisfy the needs of the military. Concerning the demand side, a higher degree of militarization could increase domestic demand for arms and this in turn could help to develop the local arms industry, but if a country cannot successfully replace imports through internal production, demand for foreign arms should be positively related to the size of the military industry.

Our central hypotheses are:

1. Economic factors: a higher level of GDP indicates higher production capabilities and hence a higher supply of MCWs. As a country succeeds in developing a more advanced military industry, its unit cost of production will decrease. However, a higher level of GDP will also imply a greater absorptive capacity, especially for countries with a large military expenditure, and hence be related with lower average exports of MCWs. The level of GDP in the importing country indicates its capacity to buy advanced military MCWs and hence also a positive relation with arms trade is expected.

2. Political orientation: it will be more likely for democracies to become exporters of MCWs, especially during the cold war, assuming that the weapons are mainly demanded for security reasons and given the threats from the USSR. However, in the post-Cold War era and given the global reduction in security treats, it will be more likely that less democratic countries become exporters. From the demand side, higher levels of democracy are related to more internal security and to a lower probability of importing MCWs. In the second stage process, the level of democracy in an exporter country does not influence the amount of the transfer, whereas for a recipient, it could be that the amount transferred decreases for destinations with lower levels of democracy, conditional on the fact that the transfer has been approved.

3. Democratic peace hypothesis: Since the level of trust between democracies is higher, countries with lower differences in democracy scores will more likely trade MCWs (a similar level of trust could also exist between autocracies). The level of voting affinity could also be related to taste similarities and strategic behavior and hence is expected to be 
positively related with the likelihood of arms transfers. As for the second stage, the volume of arms traded could be higher among democracies or autocracies mainly during the Cold War, since after 1990 other factors may play a role such as a respect for human rights and friendly diplomatic relations. Hence, we expect that voting similarity will be positively related to the amount transferred, given that the transfer has been approved, but only in the post-Cold War era.

4. Security motives (pacts, embargoes and conflicts): Pacts, and in particular defense, nonaggression and entente pacts, should increase the likelihood of exporting MCWs, since the members trust each other and are not supposed to use the weapons against the other country members of the pacts. Countries in conflict will tend to sign more transfer agreements on MCWs; however, exporters could restrict the amount exported to those countries if arms are used against minority groups or violating human rights. Hence the probability to export arms could increase with conflict in the recipient countries, but the amount transferred could decrease with conflict once we consider that not all transfers are approved.

\section{Data Description, Variables and Stylized Facts}

In our analysis, we combine information from different fields of research and various sources to measure the determinants of the arms trade. This section describes the data and the construction of the variables included in the analysis. The study covers the period from 1950 to 2007 and uses data for 104 suppliers of arms and 154 recipients, listed in Tables A.1 and A.2 in the Appendix.

\subsection{Arms trade}

The available trade classifications do not provide a straightforward identification of the arms trade and ammunition. Although recent revisions of the categories listed in the Harmonized Commodity Description and Coding System (HS) allow us to isolate exports and imports of arms and ammunition ${ }^{9}$, the data is mostly based on reports given by the importing and exporting countries ${ }^{10}$ with states often failing to fully comply with reporting regulations (Brauer, 2007). Therefore, we use data on arms transfers from the SIPRI Arms Transfers Database. It covers MCWs including air defense systems, aircrafts, anti-submarine warfare weapons, armored vehicles, artillery, engines (for

9 For example, the HS-1992 goods category has an entry for "arms and ammunition and parts and accessories thereof" (HS-93).

10 Due to confidentiality reasons, countries may not report all of their detailed trade. In data sources, such as UN Comtrade, this trade will usually be included in a category called "others" and in the total trade value. 
ships, armored vehicles and aircrafts), missiles, satellites, sensors, ships and components such as guns and turrets. Information comes from various sources including the media, governments, nongovernmental organizations (NGOs) and international institutions. The transfers can be of an official or unofficial nature and not necessarily involve a direct payment. Transfers to rebel groups or NGOs within the recipient countries are excluded from our sample.

In addition to agreements of transfers, SIPRI also provides a separate dataset with information on the value of the shipment between the two parties in the year of the delivery. This dataset is based on the known unit production costs of a core set of weapons and is intended to represent the transfer of military resources rather than the financial value or sales price of the traded amount. For used arms, the volume is reduced between 33-60 percent depending on whether it has been significantly refurbished. The reported value is referred to as the trend-indicator value (TIV) and it is given in millions of USD at constant (1990) prices. Deliveries with a value of less than USD 500,000 are denoted as a zero. When the transfer in a given year is delivered over several years, we split the number of products among the years. We have coded the information contained in the trade registers, which contain information about the year of order or license, the year(s) of delivery, as well as the number of weapons ordered and delivered, and the type of weapon. Moreover, there are comments indicating whether the transfer is an aid transfer or a licensed transfer and whether it consists of second hand weapons or not. Next, we have linked the information on trade deliveries in the trade register with the value of the shipment in the TIV dataset.

\subsection{Explanatory variables: Economic, Security and Political factors}

\subsubsection{Economic and geographical and cultural variables}

The economic variables, namely, gross domestic product (GDP) is from the Maddison Project, which is, to our knowledge, the only source of GDP data that also covers socialist or communist countries. Population data are from the World Development Indicators of the World Bank and is used to calculate GDP per capita.

Cultural and geographical characteristics are measured with several variables taken from the Centre d'Études Prospectives et d'Informations Internationales (CEPII), namely distance between capital cities and dummy variables indicating if countries share a border, use the same language, have had a colonial relationship in the past and are landlocked.

\subsubsection{Security factors}


We use data on conflicts provided by the dataset of armed conflicts from the Centre for the Study of Civil War (CSCW) and the Uppsala Conflict Data Program (UCDP) at the Department of Peace and Conflict Research at Uppsala University.

Information on mandatory UN embargoes for the whole period comes from the SIPRI Arms Embargoes Database. This data has also been completed using information from a comprehensive dataset on embargoes, which has been put together by Ericson (2013) for the period 1981 to 2004. Data on the share of military personnel comes from the National Material Capabilities (v4.0) dataset and information on military and strategic pacts comes from the Formal Alliances (v4.0) dataset of the Correlates of War Project (COW).

\subsubsection{Political factors}

In order to present a simplified picture of the global political landscape, we distinguish between two different political dimensions: the level of democracy and voting similarity as a proxy for political orientation. This gives us four main groups of governments: left-oriented democracies, rightoriented democracies, left-oriented autocracies and right-oriented autocracies (Figure 1).

\section{Figure 1. Political Dimensions}

For the level of democracy, data comes from the polity2 variable in the POLITY IV database hosted by the Center for Systemic Peace and George Mason University. It ranges from -10 (strongly autocratic) to +10 (strongly democratic). As described in Section 2, the most commonly used measure for political orientation (Comola, 2012) has several flaws. We therefore measure political orientation using a new approach, which differs from Comola (2012).

In the last sixty years, the world may have shifted from a bipolar system to a unipolar or multipolar system, but the United States remains the sole superpower. Since the United States has been the main exporter of arms in the period under study, we take the political orientation of the United States as a point of reference and measure the similarity in political orientation of a country to the United States by using the similarity index, which is based on the voting behavior in the UN General Assembly (UNGA).

The data is from the UNGA Voting Dataset by Voeten and Strezhnev (2009). The authors constructed a voting similarity index equal to the total number of votes where both states agreed and divided by the total number of joint votes. It varies between 0 and 1 (agre3un) and is computed based on three categories (approval, abstain and disapproval on an issue) and where abstention is counted as halfway between a yes or no vote. The data is described by the authors as measuring common "interests" or "preferences" and we attribute differences in the UNGA voting behavior to 
differences in the political alignment of the foreign policy. We use the similarity index for the trading countries and also the similarity between the United States and any other country in the world.

We believe that our method captures the political orientation in a more accurate way than the measure used by Comola (2012). To illustrate our argument, we give the following example: The Labour government of Tony Blair in United Kingdom (1998-2010) and the republican government of George W. Bush in the United States (2001-2008) have usually been perceived as being very similar regarding foreign policy. Nevertheless, according to the dataset of the World Bank, they hold opposing positions regarding political orientation, while their voting concordance in the UN General Assembly is among the highest for all countries during that period. Furthermore, there was substantial cooperation between the two governments in the exchange of arms. According to the SIPRI dataset, there were 44 agreements to trade arms between the two countries in the period 2001-2008, a very high number indeed.

\subsection{Stylized facts}

In what follows, we examine the evolution over decades of the correlation between both political dimensions, namely the level of democracy and the common "interest" with the United States of each country. In Figure 2 the vertical axis shows the level of democracy that varies between -10 and +10 and the degree of voting similarity between a given country and the United States over time that varies between 0 and 1 on the horizontal axis. The figure shows the scatter plot between both variables in six different years, one by decade. For each year, four quadrants are drawn to facilitate visual inspections of where countries are located. Very democratic countries (polity2>0) and with a high voting similarity index with the United States (index $>0.5$ ) are in the upper-right quadrant, whereas countries with a low polity 2 and with a below-average similarity index are in the lower-left quadrant. Conversely, the upper-left quadrant is for democratic countries with a below-average voting similarity index and the lower-right quadrant for countries with a very similar voting behavior to the United States and below-average polity2 index. Interestingly, the upper-left quadrant was empty in 1955 and only 7-8 countries move into it in the 1960s and 1970s. However, after the mid-1980s, many countries are located in it, with more than 60 countries in 2005 . The opposite trend is observed in the lower-right quadrant, which is quite populated in the first three decades, but empty in the 1980s, 1990s (almost empty) and 2000, with no countries having a high voting similarity and a low level of democracy. 
Voting similarity with the United States shows an average decline over time, and the level of democracy has risen after a downturn in the 1970s. The only persistent pattern we find is a group of highly democratic countries with relatively similar voting behavior to the United States that mostly consists of northern democracies and have been in the upper-right quadrant (e.g. UK, Sweden) but have moved slightly to the left, due to a decreasing voting similarity with the United States.

Figure 2. Political Orientation and the Level of Democracy in Single Years

Figure 3 shows the evolution over time of export shares of the main exporters of MCWs. The United States and Russia (Soviet Union until 1989) are the dominant exporters with more than 50 percent of the market in 2007, followed by Germany with a 12 percent share, France with 9 percent and the UK with almost 4 percent. The most dramatic increase in export share can be observed for China, which was supplying almost 7 percent of the market in 2016.

\section{Figure 3. The Evolution over Time of Export Shares in MCWs for Main Exporters}

Figure 4 shows the evolution over time of the value of MCWs exported indicating that the volume of exports increased for most main exporters until the late 1970s. In the early 1980s, a downward trend is observed mainly in the Soviet Union and the United States, and in other main exporters, such as France and Germany, since the mid-1980s. Both the United States and Russia started to increase their exports again after 2002 onwards, as did Germany, the UK and China. The general trend of the aggregated exports of MCWs is better seen in Figure 5, which shows the evolution over time of the volume of world exports of major arms. Two clear turning points are observed, the first in the early 1980s, when most providers started to decrease their exported volume and the second in the early 2000s, when some of the "new" exporters, such as China, started to be important players in the market and some of the "strategic" exporters started to increase their exports again".

\section{Figure 4. Evolution over Time of MCWs Export Values for Main Exporters}

Figure 5. World Exports of MCWs in USD

\footnotetext{
${ }^{11}$ This fact could be linked to the September 2011 terrorist attack and the subsequent increase in the military budgets in Western countries.
} 


\section{Empirical Strategy}

In this section, we first present the model specifications for the determinants of the probability of trading arms and of the volume traded and the two-stage estimation strategy. Secondly, we proceed to compare trade in goods with the arms trade.

\subsection{Model specification}

The econometric analysis is based on the gravity model of trade augmented with several variables that capture the political environment of the supplier and recipient countries and security factors that are expected to influence the arms trade. The gravity model has been widely used to model bilateral flows and is a suitable tool for estimating the effect of specific economic, cultural, geostrategic and political factors on trade (Head and Mayer, 2014; Baltagi et al, 2014). It was first used to estimate trade flows by Tinbergen (1962), extended with theoretical foundations by Anderson (1979) and later by Anderson \& van Wincoop (2003), which accounts for relative trade costs in the form of multilateral resistance to trade.

As explanatory factors for the arms trade, we use standard gravity variables, namely GDP and GDP per capita, the distance between a country-pair and categorical variables that control for geographical and cultural closeness (Bergstrand, 1985, 1989). In addition, we control for strategic and security motives affecting the demand and supply of arms, namely the existence of conflicts in a recipient country, arms embargoes against a recipient country and military pacts and strategic agreements between a supplier and recipient. Another factor that could be considered as strategic, we use information on the industrial capacity of the domestic arms industry ${ }^{12}$ and the domestic demand for arms. Since this information is not available for the whole period, we use the share of military personnel divided by the total population as a proxy to measure the degree of militarization in a country and the subsequent demand for military equipment.

Political factors are modelled using the above-mentioned variables: the level of democracy for a supplier and recipient, the absolute difference in both dimensions between a supplier and recipient, the voting similarity index between the United States and a supplier and reporter and the voting similarity index between the trading partners.

A Probit model is specified to estimate the determinants of the probability that countries $i$ and $j$ agree on a transfer of MCWs in year $t$ :

\footnotetext{
${ }^{12}$ The development and expansion of the domestic arms industry could also be related to the trade theories that identify imperfect competition and increasing economies of scale as an explanation for international trade (Helpman and Krugman, 1985). In this sense, the size of the arms industry could also be positively related to lower unit costs of production and to higher exports.
} 


$$
\operatorname{Pr}\left(\operatorname{Transfer}_{i j t}=1 \mid X\right)=\phi\left(\alpha+X^{\prime} \beta+\kappa_{i}+\lambda_{j}+\gamma_{t}+\varepsilon_{i j t}\right),
$$

where the dependent variable, Transfer ${ }_{i j t}$, takes the value of one if the potential importer, $j$, placed an order for MCWs from the supplier $i$, or in the case of licensed production, if a license was issued in year $t$, and zero otherwise. The vector of regressors $\mathrm{X}$ is assumed to influence the outcome and consists of the following variables ${ }^{13}: \ln \mathrm{GDP}_{\mathrm{it}}$ and $\ln \mathrm{GDP}_{\mathrm{jt}}$ denote, respectively, the natural logarithm of supplier GDP and recipient GDP in year $t$; and $\ln \mathrm{GDPpc}_{\mathrm{it}}$ and $\ln \mathrm{GDPpc}_{\mathrm{jt}}$, denote the natural logarithm of GDP per capita for countries $i$ and $j$, respectively. Trade costs are proxied by geographical and cultural distance and are measured by the natural logarithm of the distance between the capitals of $i$ and $j$ (ln Distance ${ }_{\mathrm{ij}}$ ); a dummy variable that takes the value of one if $i$ and $j$ share a border (Contiguity ${ }_{\mathrm{ij}}$ ), speak a common language (Language $\mathrm{ij}_{\mathrm{ij}}$ ) or have had a common colonial relationship $\left(\right.$ Colony $_{\mathrm{ij}}$ ); and a variable that takes the value of one if both countries are landlocked (Landlocked $\left.{ }_{i j}\right)$.

The first political dimension in the model is the level of democracy. We account for the level of democracy for a supplier (Polity ${ }_{\mathrm{it}}$ ) and recipient $\left(\right.$ Polity $\left._{\mathrm{j} t}\right)$, and the absolute difference in the level of democracy between the two (Polity_diff $\left.{ }_{\mathrm{ijt}}\right)^{14}$.

The second dimension, the voting similarity with the United States, is specified in a similar fashion for the supplier (agreeUN_United States ${ }_{\mathrm{it}}$ ), the recipient (agreeUN_United States $\mathrm{j}_{\mathrm{j}}$ ) and the voting similarity between countries $\mathrm{i}$ and $\mathrm{j}$ (agreeUN_ijt).

The degree of militarization is included for a supplier (Militarization ${ }_{i t}$ ) and recipient (Militarization $_{\mathrm{jt}}$ ). The dummy variable Conflict $\mathrm{jt}_{\mathrm{j}}$ takes the value of one when the government of a recipient country has been involved in a military conflict with another party in the last two years resulting in more than 24 battle-related deaths in the last two years. Military Pact ${ }_{\mathrm{ijt}}$ is a variable that takes the value of one if countries $i$ and $j$ have any kind of military or strategic agreement or alliance in place in year $t$. This can either be to remain neutral, a promise not to attack each other (non-aggression), to consult each other if a crisis occurs (entente) or to defend each other (defense). MandatoryUN_embargoes ${ }_{\mathrm{jt}}$ takes the value of one if a mandatory UN embargo is in place against country $j$ in year $t$.

The main concern regarding the estimation of equation (1) is finding an appropriate estimation technique to control for unobservable heterogeneity that is time invariant and country specific, or time varying and common to all countries and correlated with the error term. Given the large

\footnotetext{
13 See Table A.5 for a detailed description of all variables in the model.

${ }^{14}$ As a robustness check, we also use the square difference of the democracy scores (as in Akerman and Seim, 2014).
} 
number of observations in our sample (more than 500,000), we have chosen to include country fixed effects by "brute-force" as specified in equation (1), the disadvantage of which is the high demand in terms of computational power. According to Baltagi (2013), the bias is considerably reduced when there the number of observations is large.

Estimates of the probability of trading arms do not account for the value of the shipment but simply if a trade deal was agreed upon. Thus, exporting a single armored vehicle is given the same importance as exporting 200 fighter aircrafts. To account for the size of the shipment, we estimate a model using the value of the trade deal as the dependent variable and similar explanatory variables as in model (1):

$$
\ln \text { Volume }_{i j t}=\alpha_{0}+X^{\prime} \beta+\kappa_{i}+\lambda_{j}+\gamma_{t}+\varepsilon_{i j t}
$$

The dependent variable is the natural logarithm of the value of exported MCWs from country $i$ to country $j$ in year $t$, sourced from the SIPRI Dataset on Transferred Arms. As opposed to model (1), where $t$ specifies the year of the agreement in a trade deal, here $t$ denotes the time of the delivery of the exported arms. Thus, a trade deal that was agreed in one year and that only appears once in model (1), can be delivered over several years and appear in model (2) several times, with the value shipped for the year in question.

In model (2), the dependent variable is transformed by taking the natural logarithm, hence trade flows with a value of zero are not considered in the model. This may cause a sample selection bias associated with unobserved barriers to exporting arms that are correlated with observed factors and are important in explaining the export flow between countries $i$ and $j$. The bias could be particularly large due to the very high percentage of zeros in the dependent variable of almost 98 percent. Furthermore, due to the wide range of industries involved in the military industrial complex and the importance of firm cooperation, we expect firms in this sector to be very heterogeneous. If we do not control for this heterogeneity, estimates of the intensive margin of trade (the quantity exported) will be biased.

Following the theoretical development of Helpman et al. (2008), we estimate a two-stage model that allows us to control for unobserved firm heterogeneity and for sample selection bias. The estimation of the model consists of an extension of the Heckman (1979) two-stage approach commonly used to correct for selection bias. In this approach, two elements of the first stage estimation (a Probit model to estimate the probability of exporting arms in each single year) are used in the second stage as a proxy for firm heterogeneity and to correct for sample selection bias. The subsequent procedure for panel data sample selection models is discussed in Wooldrige and in Baltagi et al. (2014). 
In the first stage, we estimate the Probit model on the probability of trading MCWs from country $i$ to $j$ in each year $t$ :

$$
\operatorname{Pr}\left(\operatorname{Trade}_{i j t}=1 \mid X\right)=\phi\left(\alpha+X^{\prime} \beta+\kappa_{i}+\lambda_{j}+\gamma_{t}+\varepsilon_{i j t}\right),
$$

The model differs from equation (1) in the dependent variable, which in equation (3) is the probability of exporting (delivering) arms from country $i$ to country $j$ in year $t$ ( Trade $_{\mathrm{ijt}}$ ) and not the probability of placing an order or the agreement on a trade deal ${ }^{15}$. In the second stage, the dependent variable is the value of exported MCWs from country $i$ to $j$ in year $t$. The model is specified as:

$$
\begin{aligned}
& \ln \mathrm{XVal} l_{i j t}=\alpha+X^{\prime} \beta+\delta_{1} I M R+\delta_{2} \hat{Z}+\delta_{3} \hat{Z}^{2}+\delta_{4} \hat{Z}^{3}+\delta_{5} \bar{G}^{\prime} \phi+\gamma_{t}+\varepsilon_{i j t} . \\
& \text { where } \varepsilon_{i j t}=\mu_{i t}+\omega_{i j t}
\end{aligned}
$$

Following Helpman et al. (2008), we include two additional terms as regressors in the second stage. First, the linear prediction of exports from model (3) down-weighted by its standard error $(\hat{Z})$, as well as the corresponding squared and cubed term (to introduce non linearities), and the inverse Mill's ratio (IMR) also from model (3). The former terms correct the bias generated by the underlying unobserved firm-level heterogeneity, whereas the latter is a correction for sample selection, which addresses the biases generated by unobserved shocks. Model (4) is estimated using the Mundlak (1978) [and Chamberlain (1984) and Wooldridge (2002)] approach, which involves projecting the effect of the group means of the time varying variables. In a panel data framework, it is implemented by estimating a random effects Probit model augmented with the group means of the time varying variables $(\bar{G})$.

To fulfil the exclusion restriction of the Heckman approach, we use a variable that only affects the probability of exporting, but not the value exported, and hence does not enter the second step model. The variable measuring mandatory UN embargoes is the best candidate for this purpose. In fact, the assumption that mandatory embargoes, which are aimed at stopping arms exports to a given destination, only affect the probability and not the value of exports seems intuitive. Indeed, this variable yields no significant estimates when included in model (2). The intuitive explanation for this is that once a supplier of arms is willing to violate the embargo, it will do so regardless of the size of the deal.

15 The SIPRI Arms Transfers Database provides information on the order of a transfer and the value of the transfer in separate datasets with different timings. 


\subsection{Trade in Arms versus Trade in Goods}

In previous sections, we have emphasized the importance of political factors in explaining the transfers of arms. However, we have not yet answered the question of whether the impact of these factors is specific to the nature of the arms trade or whether it applies for trade flows in general. A direct comparison of estimates for all goods could provide evidence of whether the determinant of trade considered exert a different impact on trade in goods and on arms transfers, in terms of direction, extent and significance of the effect ${ }^{16}$.

In order to make a direct comparison, we construct a dataset that includes the same set of countries over the same years for trade in goods and for arms transfers. This reduces the number of observations significantly, especially for communist countries and in the early years of the period under study. Information on trade flows from goods comes from the United Nations Comtrade Database for the years 1962-2007. The empirical strategy is similar, with the only difference being that the exclusion restriction in the first step estimation of the Helpman et al. (2008) approach is not embargoes but conflicts.

\section{Main Results}

We first present estimations of the traditional gravity model of trade with three different sets of explanatory factors: economic, political and security factors, using the probability of placing an order for a shipment of MCWs as the dependent variable. Next, we present the results of the 2-stage model that considers firms heterogeneity and selection into exporting arms and goods.

Panel estimates of Model (1) for the different groups of variables measuring the different factors that influence the probability of transfer MCWs are reported in Table 1. Column (1) shows the results of the traditional gravity model with year Fixed Effects and column (2) adds exporter and importer fixed effects ${ }^{17}$. The rest of the Table shows the average marginal effect obtained for the model in column (2) for the whole period in column (3) and for the Cold War and post-Cold War periods in (4) and (5), respectively.

Estimates of the standard gravity variables, mostly have the expected signs. GDP has a significant and positive impact on the probability of agreeing on an arms transfer, while GDP per capita has a

\footnotetext{
16 A comparison between the arms trade and in goods other than arms is not straightforward. As described in section 3.1, arms or components of arms (e.g. ship engines) are often labelled as non-military goods or not reported for reasons of confidentiality.

${ }^{17}$ The large time dimension in our data set mitigates the potential bias that arises due to the incidental parameter problem in Probit panel data models with country dummy variables. The bias is of order $(1 / T)$, therefore it is lower than 2 percent in our sample.
} 
significant and negative impact for the exporter and positive impact for the importer. Geographical variables also show the expected results, with negative and significant coefficients for distance, a positive, but not significant, coefficient for a common border and a negative and significant effect for landlocked countries, but only in column (1). Cultural similarities, measured by a shared colonial past and common official language, show a positive and significant effect for colonial links and a non-significant effect for common language ${ }^{18}$.

The variables that serve as a proxy for the country-specific level of democracy have a statistically significant impact on the probability of ordering an arms transaction in column (1) and column (2), the score of democracy has a positive effect on the likelihood of exporting arms and a negative effect on the likelihood of importing arms. In other words, an increase in the polity index of a supplier, significantly increases the probability of exporting arms; whereas the effect of a decrease in the polity score increases the probability to receive arms for a recipient. The effect of the exporter's level of democracy changes direction in the post-Cold War period, when it is also negative and significant (column 5), indicating that after the 1990s less democratic countries are more likely to export arms.

With respect to voting with the United States, the estimates loss significance when adding country fixed effects and switch sign in case of the supplier. The results in column (2) indicate that countries with a higher voting similarity score are less likely to become arms exporters and/or importers. However, the coefficient of the voting similarity score between trading partners is positive and significant, but only during the Cold War period, showing that countries with similar "strategic preferences" were more likely to conduct arms transfer agreements.

These effects become non-significant in the post-Cold War period, indicating that the voting similarity as a proxy of "strategic" friends has lost importance over time. However, this is not the case for the democracy scores that remain significant after 1990 (column 5). The main change is that the effect of the democracy level in the exporter country changes from negative to positive, indicating that more democratic countries are more likely to agree in transferring arms after 1990.

Concerning the differences in political factors between trading countries, an increase in the absolute difference between the polity scores between countries $i$ and $j$ has a significant negative impact on the probability of making a trade deal before and after 1990, but increasing similarity in voting behavior only seems to have an effect during the Cold War years and not after (column 5).

\footnotetext{
${ }^{18}$ When estimating the model with only gravity variables, only political variables and only security factors, the Pseudo $\mathrm{R}^{2}$ equals respectively, $0.30,0.16$ and 0.06 .
} 
Comparing our results with Akerman and Seim (2014), they found that differences in the political orientation do have a significant impact on the probability of two countries engaging in an arms trade, but only before and not after 1989, whereas in our results the coefficient is significant in both periods. This could be because their post war sample only contains 11 years and thus there is not enough information to obtain an accurate estimate ${ }^{19}$. Nevertheless, it is worth mentioning that we find an overall loss of significance of the UN voting similarity variables in the post-Cold War period.

Security factors are also relevant. While military pacts and conflicts in the recipient countries always significantly increase the probability of ordering a transfer, embargoes against a recipient have a negative impact. It is worth noting that the impact of the military pact halves in the period after 1990 (column 5, Table 1) and the impact of conflicts increased by one-third. In comparative terms, pacts exerted much greater influence on the probability of trading arms during the Cold War, but remain more important than conflicts in the post-Cold War. The average marginal effects reported in columns (3) to (6) indicate that a pair of countries with a military pact have a 2.1 percent greater probability to order a transfer than those without. Similarly, when there is a conflict in a recipient country, the probability of ordering an arms trade is 0.5 percent higher than for countries not in conflict (column 3 in Table 1). Countries with mandatory embargoes have a 1 percent lower probability of ordering an arms trade. Interestingly, militarization in the exporting country makes trade deals more likely to happen during the Cold War period (column 4), supporting the economies-of-scale argument; whereas in the second period, the opposite is true, indicating that increases in military personnel tend to reduce the probability of approving arm transfers (column 5), perhaps due to an increase in the domestic use of arms. The effect in the post-Cold War era almost triples that of the previous period. Militarization of the importer country, which is used as a proxy for the domestic demand of arms, has a negative but non-significant effect on the probability of importing arms in any of the specifications.

\section{Table 1: Probability of Agreeing on an Arms Transfer}

Regression results using the traded value of arms as the dependent variable are shown in Table $2^{20}$. The first column of Table 2 shows the results for model (2) using a panel random effects model,

\footnotetext{
${ }^{19}$ See the robustness section for a closer replication of the results in Akerman and Seim (2014).

${ }^{20}$ When estimating the model with only gravity variables, only political variables and only security factors, the Pseudo
} 
extended with the average of the time variant variables. To control for various biases described above, we show results for the second step of the Helpman et al. (2008) approach in columns (2) to (4) of Table 2, first controlling for selection bias by introducing the inverse Mills Ratio in column (2), next, controlling for the extensive margin of trade using the prediction obtained from a Probit model estimated for single years in column (3) and for both factors in column (4), which corresponds to model (4). Results for pre- and post-Cold War periods from model (4) are also shown in columns (5) and (6) of Table 2.

The estimates are substantially different from the ones shown for the probability of ordering a transfer and are indeed not comparable. Concerning the policy variables, we can see in column (1) that the level of democracy of the supplier shows a non-significant estimate, different to Comola $(2012)^{21}$, and a non-significant estimate of the level of democracy in the importing country and of the differences in polity in columns (2) and (4) after controlling for sample selection. Instead, the democracy-difference coefficient is positive and statistically significant in columns (5) for the Cold War period, indicating that a twenty-point increase in the difference in country's level of democracy increases the value of the arms exported by around 0.56 percent (column (5)), indicating that the amounts traded with less similar countries in terms of democracy scores are on average higher in magnitude, conditional on the transfer having been approved.

The coefficients of the supplier's and the recipient's voting concordance with the United States in the UN General Assembly are non-significant in column (1), but when controlling for sample selection (columns (2) and (4)) the estimate of the exporter voting similarity with the United States turns out to be negative and significant, indicating that decreasing voting similarity is associated with higher export values, once the transfers have been approved. Interestingly, this result is due to the coefficient being significant during the Cold War period only. Indeed, when the countries have a more similar voting pattern to the United States, they tend to transfer smaller amounts of arms, whereas the importer's voting similarity with the United States does not seem to affect the amount of MCWs transferred. With respect to the voting similarity between the trading countries (agreeUN_ij), controlling for selection bias renders the coefficient non-significant for the entire sample period (columns (2) and (4)). However, in the post-Cold War period, countries with similar "political" preferences trade higher amounts of arms (column (6)), indicating that good diplomatic

\footnotetext{
$\mathrm{R}^{2}$ equals respectively, $0.18,0.09$ and 0.09 .

${ }^{21}$ Comola's (2012) specification is substantially different to ours; she models separated exporter and importer fixed effects and the estimation method is a Tobit, instead of method Mundlak approach. Also, the sample of countries and years is different; she considers only the 20 major MCW producers over the period 1975-2004, whereas we consider all countries that export arms over the period 1950-2007.
} 
relations turned relevant in the nineties, whereas differences in the level of democracy no longer plays a role.

With respect to the security motives, a military or strategic pact signed between a supplier and recipient increases the volume of arms transferred by about 37 percentage points according to results in column (1), when not controlling for selection bias; however, conditional on the transfer having been approved, military pacts no longer determine the value of the transfer. With respect to conflict in a recipient country, the existence of a conflict in the two previous years positively affects arms transfers in the estimates in column (1), but once we control for selection bias, the coefficient turns negative, indicating that conditional on the transfer having been approved, the value of arms transferred to countries in conflict are around 20 percent lower than those sent to countries without internal conflicts.

A mandatory embargo by the $\mathrm{UN}$ on a recipient had a non-significant effect on the volume of arms exported and hence, this variable has been excluded from the second stage to fulfil the exclusion restriction of the model. We have also excluded the degree of militarization of the society because it is not statistically significant in the second stage. This means that militarization in the exporter and importer countries also serve as exclusion variables.

Regarding the other control variables, the value of arms transferred tends to be higher for suppliers and recipients with higher GDP and lower GDP per capita. However, the results are less consistent once the sample is divided into the Cold War and post-Cold War periods (columns (5) and (6)). On the other hand, recipient GPD and GDP per capita are only significant in the first period, indicating that only economic factors from the demand side are relevant, in column (6) GDP per capita are not significant and the coefficient of the exporter GDP is negative and significant, hiding perhaps nonlinearity effects ${ }^{22}$.

Geographical characteristics, such as being a landlocked country, are not relevant in determining the value of exports, once a transfer has been approved, whereas sharing a border has a negative and significant effect on the value of arms exported for the entire period (column (4), coming mainly from the result for the Cold War period in column (5), since after 1990 the coefficient is not statistically significant).

It may seem surprising that distance between a supplier and recipient has a significant and positive impact on the volume of arms exported if we assume that larger distances translate to higher

\footnotetext{
${ }^{22}$ Using common religion as additional variable in the first stage regression renders the coefficient of GDP in the exporter country in column (6) non-significant, while the rest of results remain very similar.
} 
transport costs. However, as indicated previously in the paper, the positive effect of distance can be explained by the fact that suppliers prefer selling large amounts of arms to more distant destinations to lessen the chance of subsequently facing these arms in battle. While a shared colonial past between a supplier and recipient has a positive impact on trade volume, the common language shows a negative effect, but mainly due to the Cold War period.

Summarizing, we find no impact of democracy levels and democracy differences between a supplier and recipient on the value exported for estimations that include controls for sample selection bias and firm heterogeneity. The same happens with variables controlling for pacts between a supplier and recipient in the regressions with bilateral fixed effects.

The fact that the inverse Mill's ratio is negative and significant in the second stage for the randomeffects estimation, indicates that there is evidence that selection bias is quantitatively important in this model, and that unobservables that affect both the probability of transfer arms and the value of the transfer are negatively correlated.

\section{Table 2: Value of the Arms Trade}

Next, we identify differences between the political determinants for the arms trade and the trade in goods by using identical models to estimate the probability of exporting arms and goods and to estimate the determinants of the value of traded arms and goods. The sample period is reduced to 1962-2007 to ensure that the estimations are comparable, as described above.

Table 3 shows the main results. The first two columns are estimated using a Probit model with country and time fixed effects as shown in Table 1; whereas the results in columns (3) and (4), are from the second step of the Helpman et al. (2008) procedure estimated using a Random Effects model augmented with the time averages of the time variant variables (as in Table 2). When comparing the results for the probability of transferring arms with that for the trade in goods in column (1) and (2) of Table 3, we find that the level of democracy affects both types of trade, but the magnitude and sometimes the direction of the effect differ. With respect to the probability of ordering an arms trade, more democratic exporters are likely to export more goods and more arms, whereas more democratic importers are likely to import more goods but receive fewer arms. The magnitude of the effects is four times higher for arms than for goods. With respect to the voting similarity with the United States, the effect is only positive and significant for the probability of trading goods, but not for arms. 
Concerning the value of exported arms (columns (3) and (4) in Table 3), the levels of democracy in the exporter and importer countries do affect the value of goods exported, but not of arms, whereas the difference in democracy levels is positively related to the trade in goods only.

Meanwhile, exporting countries tend to export more arms when they are less aligned with the United States in terms of voting similarity, whereas for total goods the effect is much smaller. Voting-behavior similarity between the exporter and importer appear to affect the volume in the same direction, but the effect is only statistically significant for the trade in goods.

\section{Table 3: Arms vs. Goods (1962-2007)}

In order to validate the results obtained, we carry out a number of robustness checks. First, we replicate the results in Table 1 for the 20 main exporters. Second, we estimate separate models for individual exporters. Then, we estimate the model replicating Akerman and Seim (2014). Finally, we consider lagged variables to account for potential endogeneity biases.

The models estimated for the 20 main exporters are in Table A.6. The results, in terms of direction of the effects and significance levels, are similar to those obtained in Table 1 for 104 exporters. However, the marginal effects are much higher in Table A.6 than in Table 1, which is expected since these 20 exporters cover more than 95 percent of the market in MCWs. For example, having a military pact increases the probability of exporting MCWs by 10 percent according to the results in Table A.6, whereas when all exporters are considered, the marginal effect indicates that the probability of exporting MCWs for countries that have a military pact is only 2 percent higher.

The results for single exporters are shown in Table A.7. The model is estimated using a Probit with time fixed effects for the United States, Russia, United Kingdom and France in columns (1) to (4), respectively. In the model for single exporters, we only include political factors that vary by origin and destination. In column (1) with the United States as exporter, the difference in democracy levels shows no influence in the probability of exporting, whereas the voting similarity index shows a positive and significance coefficient ${ }^{23}$, that is almost three times the one shown in Column (2) for Russia and four times the coefficient of the UK. Differences in the level of democracy seems to be affecting only the UK's exports, whereas the security factors, namely conflicts, pacts and embargoes, are particularly relevant for the United States and Russia, the so called strategic exporters. What we learn from the estimation for single exporters is that there is great heterogeneity

\footnotetext{
${ }^{23}$ This is in accordance with Blanton (2005), in that it could be due to the United States' support for countries in close political alignment.
} 
in the estimated parameters. We leave for further research a most comprehensive identification of the main factors affecting not only the extensive margin, but also the intensive margin of exports for each main exporter of MCWs.

As a third robustness check, a replication of Akerman and Seim (2014) is presented in Table A.8. We obtain a negative and significant coefficient for the variable measuring the square differences in polity2 (Polity_diff) ${ }^{2}$, but the magnitude of the coefficient is slightly different to the one reported in Akerman and Seim (2014), possibly due to the different number of observations in the sample ${ }^{24}$. The main divergence in results is that in our results the negative correlation between the differences in polity and the likelihood of an arms trade is still present in the post-Cold War period (column 5), whereas in column (10) of Akerman and Seim (2014), the coefficient is not statistically significant.

We also evaluate the possible endogeneity of the voting similarity measures. A potential recipient of arms could alter its voting behavior to please or appease a potential supplier and boost the chances of making a deal. We test for the existence of an endogeneity bias by using a three-year lag of all variables measuring political orientation ${ }^{25}$. The results are shown in Table A.7 in the Appendix. According to our estimates, the bias, if it exists at all, is quantitatively very small and does not affect the main results.

\section{Conclusions}

The results presented in this paper show the impact of several economic, political and security factors on the probability and the value of arms transfers. We find that the level of democracy and the political orientation of the supplier and recipient countries, as well as the differences between them, are important determinants of the probability of trading arms. While suppliers with higher levels of democracy have a higher probability of transferring arms, we find the opposite to be true for the importer countries. However, these effects change in the post-Cold War period, when less democratic suppliers have a higher probability of transferring arms and the level of democracy in importer countries shows a decreasing effect on the probability of making a deal.

In addition, when a country is -politically speaking- more closely oriented to the United States, specifically referring to higher voting similarity in the UN Security Council, the country is less likely to export and import MCWs, but the result only holds for the Cold War period, whereas after

\footnotetext{
${ }^{24}$ We estimate the model with OLS (linear probability model) without (column 1 ) and with exporter and importer fixed effects (column 2). Columns (3) to (5) also include year dummies (time fixed effects). Akerman and Seim (2014) do not mention the inclusión of time fixed effects, which in any case should be added to the model to control for unobserved heterogeneity that is common to all country-pairs and varies over time.

${ }^{25}$ Results are available upon request.
} 
1990, the statistical significance disappears. When two countries tend to be close in terms of voting similarity, they are more likely to agree to an arms trade, but again only when the model is estimated for in the Cold War period.

Regarding the security factors, countries that are involved in conflicts are more likely to import arms, while countries under a UN embargo are less likely to do so. Militarization in the exporter country is positively correlated with the probability of transferring arms during the Cold War and negatively correlated in the post-Cold War period.

In the second set of estimations, we analyze the determinants of the value of arms transfers, taking into account the two-stage decision process. The main results show that political factors are less relevant in explaining the value of the arms trade than in explaining the probability of trading arms. Indeed, we find no impact of the exporter and importer democracy levels and variables measuring democracy-level differences between a supplier and recipient on the value exported, once we control for sample selection bias and firm heterogeneity. The same happens with variables controlling for pacts between a supplier and recipient when the entire period is examined.

The fact that the inverse Mill's ratio is negative and significant in the second stage model indicates that there is evidence that selection bias is quantitatively important in this model, and that unobservable factors that affect both the probability of an arms transfer and the value of the transfer are negatively correlated. The impact of some variables also changes with the end of the Cold War. More specifically, the polity difference coefficient is positive and statistically significant only for the Cold War period, indicating that the amounts traded with less similar countries in terms of democracy scores are on average higher in magnitude, conditional on the transfer having been approved. The coefficients of the supplier's voting concordance with the United States in the UNGA is negative and significant when controlling for sample selection, indicating that increasing voting similarity with the United States is associated with lower exported values, once the transfers have been approved, but only during the Cold War period. Furthermore, the importer's voting similarity with the United States does not seem to affect the amount of MCWs transferred. With respect to the voting similarity between the trading countries, in the post-Cold War, countries with similar "political" preferences trade higher amounts of arms indicating that good diplomatic relations turn out to be relevant in the nineties, whereas differences in the level of democracy no longer plays a role.

With respect to the security motives, a military or strategic pact signed between a supplier and recipient increases the volume of arms transferred when we do not control for selection bias; 
however, conditional on the transfer having been approved, military pacts no longer determine the value of the transfer. With respect to conflict in a recipient country, the existence of a conflict in the two previous years, once we control for selection bias, is negatively correlated to the average value of arms transferred, indicating that conditional on the transfer having been approved, the value of arms transferred to countries in conflict is around 20 percent lower than those sent to countries without internal conflicts.

We also find that political determinants also play an important role in explaining the flow of goods between countries, but that the size of the impact is larger for the transfer of arms.

Our results are robust to a number of sensitivity tests, including reducing the sample to the main twenty exporters and to potential reverse causality between UNGA voting behavior and agreements to transfer arms. Moreover, the results for single exporters show that it is important to account for heterogeneity in the effects across exporters.

Overall, our results suggest that the political closeness between a pair of countries is an important determinant of an arms transfer, in addition to economic and strategic interests. Any attempt to regulate the trade of major conventional weapons should therefore reflect the political interests involved. Mandatory UN embargoes appear to be successful in decreasing the probability of arms transfers but do not have a significant impact on the value of the arms traded.

Moreover, our results concerning the voting similarity with the United States show that arms transactions generate less dependence today than in the past, as suggested by Catrina (1988); and there are other factors that are more likely to generate dependence such as economic vulnerability or political stability. In this sense, it is crucial to consider political factors, such as the level of democracy or the political orientation, as explanatory factors of the arms trade.

\section{References}

Akerman, A. \& Seim, A.L., 2014. The Global Arms Trade Network 1950-2007. Journal of Comparative Economics, 42(3), pp. 535-551.

Anderson, J.E., 1979. A Theoretical Foundation for the Gravity Equation. American Economic Review, 69(1), pp.106-16.

Anderson, J.E. \& van Wincoop, E., 2003. Gravity with Gravitas: A Solution to the Border Puzzle. American Economic Review, 93(1), pp.170 - 192. 
Anderton, C.H., 1995. Economics of Arms Trade. Handbook of Defense Economics, Volume 1, Edited by K. Hartley and T Sandler. Chapter 18 in pp. 524-559.

Baltagi, B., 2013. Econometric Analysis of Panel Data 5th ed., John Wiley \& Sons.

Baltagi, B., P. Egger and M. Pfaffermayr, 2014. Panel data gravity models of international trade," CESifo Working Paper No. 4616.

Bergstrand, J.H. 1985. The Gravity Equation in International Trade: Some Microeconomic Foundations and Empirical Evidence, The Review of Economics and Statistics 67, pp. 474481.

Bergstrand, J.H. 1989. The Generalized Gravity Equation, Monopolistic Competition, and the Factor-Proportions Theory in International Trade. Review of Economics and Statistics 71(1), pp. 143-153.

Blanton, S.L., 2000. Promoting Human Rights and Democracy in the Developing World: U.S. Rhetoric versus U.S. Arms Exports. American Journal of Political Science, 44(1).Blanton, S.L., 2005. Foreign Policy in Transition? Human Rights, Democracy, and U.S. Arms Exports. International Studies Quarterly 49, 647-667.

Brauer, J., 2007. Arms Industries, Arms Trade, and Developing Countries. In Handbook of Defense Economics. Elsevier, pp. 973-1015.

Brauer, J., 2000. Potential and Actual Arms Production: Implications for the Arms Trade Debate. Defence and Peace Economics, 11(3), pp.461-480.

Brauer, J. \& Dunne, J.P., 2011. Arms Trade Offsets: What Do We Know? In Handbook on the Political Economy of War. University of the West of England, Department of Economics, pp. $243-265$.

Bromley, M., Cooper, N. and Holtom, P., 2012. The UN Arms Trade Treaty: arms export controls, the human security agenda and the lessons of history. International Affairs 88(5), pp. 10291048.Chan, S. 1997. In Search of Democratic Peace: Problems and Promise. Mershon International Studies Review 41 (59-91).

Catrina, C., 1988. Arms Transfers and Dependence. New York: Taylor and Francis.

Catrina, C., 1994. Main Directions of Research in the Arms Trade. Annals of the American Academy of Political and Social Science 535, pp. 190-205.

Comola, M., 2012. Democracies, Politics and Arms Supply: A Bilateral Trade Equation. Review of International Economics, 20(1), pp.150-163. 
Erickson, J. 2013. Stopping the Legal Flow of Weapons: Compliance with Arms Embargoes, 19812004. Journal of Peace Research, 50 (2), 159-174.

Feenstra, R.C., 2015. Advanced International Trade: Theory and Evidence. $2^{\text {nd }}$ Edition. Princeton, New Jersey: Princeton University Press.

Fleurant, A., Wezeman, P. D., Wezeman, S. T. et al., 2017. Trends in International Arms Transfers, 2016 (SIPRI: February 2017).

Head, K., and T. Mayer, 2014. Gravity equations: Workhorse, toolkit, and cookbook, in Gopinath, G., E. Helpman and K. Rogoff (eds.): Handbook of International Economics, Vol. 4, pp. 131195, Amsterdam, Elsevier-North Holland.

Heckman, J.J., 1979. Sample selection bias as a specification error, Econometrica 47, pp. 153-61.

Helpman, E., Melitz, M. \& Rubinstein, Y., 2008. Estimating Trade Flows: Trading Partners and Trading Volumes. The Quarterly Journal of Economics, 123(2), pp.441-487.

Kinsella, 1998. Arms transfer dependence and foreign policy conflict. Journal of Peace Research, 35, pp. 7-23.

Kinsella, D., 2000. Arms Production in the Third Tier: An Analysis of Opportunity and Willingness," International Interactions 26(3), pp. 253-286.

Krause, K., 1991. Military Statecraft: Power and Influence in Soviet and American Arms Transfer Relationships. International Studies Quarterly 35, pp. 313-336.

Krause, K., 1992. Arms and the State: Patterns of Military Production and Trade. New York: Cambridge University Press.

Laurance, E.J., 1992. The International Arms Trade. New York: Lexington Books.

Levine, P. and Smith, R. 1997. The Arms Trade. Economic Policy. Vol. 12 (25), pp. 335-370.

Mundlak, Y., 1978. On the Pooling of Time Series and Cross Section Data. Econometrica, 46(1), pp.69-85.

Sislin, J., 1994. Arms as Influence: The Determinants of Successful Influence. The Journal of Conflict Resolution, 38(4), pp. 665-689.

Smith, R. and A. Tasiran, 2005. The Demand for Arms Imports," Journal of Peace Research, 42, 
pp. $167-81$.

Smith, R. and A. Tasiran, 2010. Random Coefficient Models of Amrs Imports. Economic Modelling, 27 (6), pp. 1522-1528.

Tinbergen, J., 1962. Shaping the World Economy; Suggestions for an International Economic Policy, New York: Twentieth Century Fund.

Voeten, E., Strezhnev, A., Bailey, M., 2009. United Nations General Assembly Voting Data, hdl:1902.1/12379, Harvard Dataverse, V17.

Williams, Richard. 2012. Using the margins command to estimate and interpret adjusted predictions and marginal effects. The Stata Journal 12(2), pp. 308-331.

Wooldridge, J.M., 2005. Simple Solutions to the Initial Conditions Problem in Dynamic, Nonlinear Panel Data Models with Unobserved Heterogeneity. Journal of Applied Econometrics 20(1), pp. 39-54. 


\section{Tables}

Table 1: Probability of Agreeing on a Shipment of Arms

\begin{tabular}{|c|c|c|c|c|c|}
\hline DEP.VAR. : Transfer Dummy & (1) & (2) & (3) & (4) & (5) \\
\hline Period & 1950-2007 & 1950-2007 & 1950-2007 & Cold War & Post Cold War \\
\hline IND. VARIABLES & All & All MRT & \multicolumn{3}{|c|}{ Average Marginal Effects } \\
\hline Ln GDP_i & $\begin{array}{c}0.405 * * * \\
(0.0129)\end{array}$ & $\begin{array}{c}0.564 * * * \\
(0.0691)\end{array}$ & $\begin{array}{c}0.0148 * * * \\
(0.00185)\end{array}$ & $\begin{array}{c}0.0166 * * * \\
(0.00454)\end{array}$ & $\begin{array}{c}0.00701 \\
(0.00428)\end{array}$ \\
\hline Ln GDP_j & $\begin{array}{l}0.102 * * * \\
(0.00945)\end{array}$ & $\begin{array}{c}0.0608 \\
(0.0614)\end{array}$ & $\begin{array}{c}0.00159 \\
(0.00161)\end{array}$ & $\begin{array}{c}0.00796^{* * *} \\
(0.00295)\end{array}$ & $\begin{array}{l}0.00897^{*} \\
(0.00463)\end{array}$ \\
\hline Ln GDPpc_i & $\begin{array}{c}-0.0576^{* *} \\
(0.0268)\end{array}$ & $\begin{array}{c}-0.393 * * * \\
(0.0693)\end{array}$ & $\begin{array}{c}-0.0103 * * * \\
(0.00184)\end{array}$ & $\begin{array}{l}-0.00469 \\
(0.00486)\end{array}$ & $\begin{array}{l}-0.00971^{*} \\
(0.00525)\end{array}$ \\
\hline Ln GDPpc_j & $\begin{array}{c}0.0198 \\
(0.0185)\end{array}$ & $\begin{array}{l}0.177 * * * \\
(0.0550)\end{array}$ & $\begin{array}{c}0.00465 * * * \\
(0.00144)\end{array}$ & $\begin{array}{l}-0.00254 \\
(0.00268)\end{array}$ & $\begin{array}{l}-0.00445 \\
(0.00446)\end{array}$ \\
\hline Ln distcap & $\begin{array}{c}-0.119 * * * \\
(0.0180)\end{array}$ & $\begin{array}{c}-0.160 * * * \\
(0.0244)\end{array}$ & $\begin{array}{c}-0.00420 * * * \\
(0.000649)\end{array}$ & $\begin{array}{c}-0.00519 * * * \\
(0.000916)\end{array}$ & $\begin{array}{c}-0.00493 * * * \\
(0.000942)\end{array}$ \\
\hline Landlocked_ij & $\begin{array}{c}-0.0753^{* *} \\
(0.0341)\end{array}$ & $\begin{array}{c}0.134 \\
(0.273)\end{array}$ & $\begin{array}{c}0.00350 \\
(0.00716)\end{array}$ & $\begin{array}{l}0.000212 \\
(0.00889)\end{array}$ & $\begin{array}{c}0.0232 \\
(0.0156)\end{array}$ \\
\hline Colony & $\begin{array}{l}0.555^{* * *} \\
(0.0531)\end{array}$ & $\begin{array}{r}0.517 * * * \\
(0.0497)\end{array}$ & $\begin{array}{l}0.0184 * * * \\
(0.00232)\end{array}$ & $\begin{array}{l}0.0212 * * * \\
(0.00172)\end{array}$ & $\begin{array}{c}0.00831 * * * \\
(0.00284)\end{array}$ \\
\hline Comlang & $\begin{array}{c}0.0546 \\
(0.0381)\end{array}$ & $\begin{array}{c}0.0658 \\
(0.0449)\end{array}$ & $\begin{array}{c}0.00178 \\
(0.00125)\end{array}$ & $\begin{array}{l}-0.000885 \\
(0.00158)\end{array}$ & $\begin{array}{l}0.00388^{*} \\
(0.00204)\end{array}$ \\
\hline Contig & $\begin{array}{c}0.0234 \\
(0.0735)\end{array}$ & $\begin{array}{c}0.0826 \\
(0.0680)\end{array}$ & $\begin{array}{c}0.00227 \\
(0.00196)\end{array}$ & $\begin{array}{c}0.00361 \\
(0.00253)\end{array}$ & $\begin{array}{c}0.00318 \\
(0.00288)\end{array}$ \\
\hline Polity2ip_i & $\begin{array}{c}0.0134 * * * \\
(0.00237)\end{array}$ & $\begin{array}{c}0.0265^{* * *} \\
(0.00362)\end{array}$ & $\begin{array}{c}0.000695^{* * *} \\
(9.46 \mathrm{e}-05)\end{array}$ & $\begin{array}{c}0.000493 * * * \\
(0.000148)\end{array}$ & $\begin{array}{c}-0.000522 * * \\
(0.000230)\end{array}$ \\
\hline Polity2ip_j & $\begin{array}{c}-0.0142 * * * \\
(0.00273)\end{array}$ & $\begin{array}{c}-0.0209 * * * \\
(0.00290)\end{array}$ & $\begin{array}{c}-0.000548^{* * *} \\
(7.66 \mathrm{e}-05)\end{array}$ & $\begin{array}{c}-0.000526^{* * *} \\
(0.000107)\end{array}$ & $\begin{array}{c}-0.000463 * * * \\
(0.000176)\end{array}$ \\
\hline Poldif_ij & $\begin{array}{c}-0.0220^{* * *} \\
(0.00248)\end{array}$ & $\begin{array}{c}-0.0245^{* * *} \\
(0.00255)\end{array}$ & $\begin{array}{c}-0.000644^{* * *} \\
(6.73 \mathrm{e}-05)\end{array}$ & $\begin{array}{c}-0.000721^{* * *} \\
(9.30 \mathrm{e}-05)\end{array}$ & $\begin{array}{c}-0.000830^{* * *} \\
(0.000109)\end{array}$ \\
\hline AgreeUN_US_i & $\begin{array}{c}1.032 * * * \\
(0.104)\end{array}$ & $\begin{array}{l}-0.120 \\
(0.107)\end{array}$ & $\begin{array}{l}-0.00314 \\
(0.00282)\end{array}$ & $\begin{array}{c}-0.0165 * * * \\
(0.00426)\end{array}$ & $\begin{array}{l}-6.38 \mathrm{e}-05 \\
(0.00525)\end{array}$ \\
\hline AgreeUN_US_j & $\begin{array}{c}-0.411 * * * \\
(0.106)\end{array}$ & $\begin{array}{l}-0.219^{*} \\
(0.127)\end{array}$ & $\begin{array}{l}-0.00573^{*} \\
(0.00333)\end{array}$ & $\begin{array}{c}-0.0142 * * * \\
(0.00442)\end{array}$ & $\begin{array}{l}-0.000493 \\
(0.00744)\end{array}$ \\
\hline AgreeUN_ij & $\begin{array}{l}0.331 * * * \\
(0.0380)\end{array}$ & $\begin{array}{l}0.114 * * \\
(0.0510)\end{array}$ & $\begin{array}{l}0.00299 * * \\
(0.00134)\end{array}$ & $\begin{array}{l}0.00408^{* *} \\
(0.00193)\end{array}$ & $\begin{array}{c}0.00228 \\
(0.00179)\end{array}$ \\
\hline Militarization_i & $\begin{array}{c}25.17 * * * \\
(1.337)\end{array}$ & $\begin{array}{c}0.534 \\
(2.899)\end{array}$ & $\begin{array}{c}0.0140 \\
(0.0761)\end{array}$ & $\begin{array}{c}0.273 * * * \\
(0.100)\end{array}$ & $\begin{array}{c}-0.875^{* * *} \\
(0.214)\end{array}$ \\
\hline Militarization_j & $\begin{array}{c}2.045 \\
(1.720)\end{array}$ & $\begin{array}{l}-1.773 \\
(2.049)\end{array}$ & $\begin{array}{l}-0.0465 \\
(0.0537)\end{array}$ & $\begin{array}{l}-0.0520 \\
(0.0736)\end{array}$ & $\begin{array}{l}-0.165 \\
(0.112)\end{array}$ \\
\hline Conflict last 2 years $\_j$ & $\begin{array}{c}0.218 * * * \\
(0.0249)\end{array}$ & $\begin{array}{c}0.175 * * * \\
(0.0247)\end{array}$ & $\begin{array}{c}0.00490 * * * \\
(0.000742)\end{array}$ & $\begin{array}{c}0.00428 * * * \\
(0.000957)\end{array}$ & $\begin{array}{c}0.00598 * * * \\
(0.00146)\end{array}$ \\
\hline Military pact & $\begin{array}{c}0.397 * * * \\
(0.0403)\end{array}$ & $\begin{array}{c}0.564 * * * \\
(0.0455)\end{array}$ & $\begin{array}{c}0.0196^{* * *} \\
(0.00204)\end{array}$ & $\begin{array}{c}0.0216^{* * *} \\
(0.00181)\end{array}$ & $\begin{array}{c}0.0124 * * * \\
(0.00248)\end{array}$ \\
\hline MandatoryUN_embargoes & $\begin{array}{c}-0.495 * * * \\
(0.155)\end{array}$ & $\begin{array}{c}-0.554 * * * \\
(0.155)\end{array}$ & $\begin{array}{c}-0.0103^{* * *} \\
(0.00190)\end{array}$ & & $\begin{array}{c}-0.00997 * * * \\
(0.00247)\end{array}$ \\
\hline Year dummies & yes & yes & yes & yes & yes \\
\hline Country dummies & no & yes & yes & yes & yes \\
\hline Observations & 530,205 & 530,205 & 530,205 & 273,521 & 186,549 \\
\hline Pseudo $\mathrm{R}^{2}$ & 0.346 & 0.435 & & 0.480 & 0.361 \\
\hline Log likelihood & -30203 & -26094 & & -14429 & -10942 \\
\hline
\end{tabular}

Notes: Robust standard errors in parentheses are clustered at the country-pair level. ${ }^{* * *} \mathrm{p}<0.01,{ }^{* *} \mathrm{p}<0.05,{ }^{*} \mathrm{p}<0.1$. 
Table 2: Determinants of Arms Exports

\begin{tabular}{|c|c|c|c|c|c|c|}
\hline $\begin{array}{l}\text { DEP. VAR. } \\
\text { Ln Exports }\end{array}$ & & & $50-2007$ & & 1950-1989 & $1990-2007$ \\
\hline IND. VARIABLES & $\begin{array}{c}(1) \\
\text { Baseline }\end{array}$ & $\begin{array}{c}(2) \\
\text { Selection } \\
\end{array}$ & $\begin{array}{c}(3) \\
\text { Firm Het. }\end{array}$ & $\begin{array}{c}(4) \\
\text { Sel+FH } \\
\end{array}$ & $\begin{array}{c}(5) \\
\text { Sel+FH } \\
\end{array}$ & $\begin{array}{c}(6) \\
\text { Sel+FH } \\
\end{array}$ \\
\hline Ln GDP_i & $\begin{array}{c}0.873 * * * \\
(0.235)\end{array}$ & $\begin{array}{c}0.499 * * \\
(0.246)\end{array}$ & $\begin{array}{c}0.693 * * * \\
(0.227)\end{array}$ & $\begin{array}{l}0.397 * \\
(0.238)\end{array}$ & $\begin{array}{c}0.277 \\
(0.441)\end{array}$ & $\begin{array}{c}-0.534 * * \\
(0.263)\end{array}$ \\
\hline Ln GDP $\mathrm{j}$ & $\begin{array}{c}0.994 * * * \\
(0.201)\end{array}$ & $\begin{array}{c}0.824 * * * \\
(0.203)\end{array}$ & $\begin{array}{c}0.953 * * * \\
(0.204)\end{array}$ & $\begin{array}{c}0.773 * * * \\
(0.206)\end{array}$ & $\begin{array}{c}1.141 * * * \\
(0.280)\end{array}$ & $\begin{array}{l}0.442 * \\
(0.267)\end{array}$ \\
\hline Ln GDPpc_i & $\begin{array}{c}-1.203 * * * \\
(0.247)\end{array}$ & $\begin{array}{c}-0.917 * * * \\
(0.250)\end{array}$ & $\begin{array}{c}-1.003 * * * \\
(0.241)\end{array}$ & $\begin{array}{c}-0.797 * * * \\
(0.245)\end{array}$ & $\begin{array}{l}-0.277 \\
(0.543)\end{array}$ & $\begin{array}{c}0.164 \\
(0.274)\end{array}$ \\
\hline Ln GDPpc $\mathrm{j}$ & $\begin{array}{c}-0.516 * * * \\
(0.166)\end{array}$ & $\begin{array}{c}-0.511 * * * \\
(0.168)\end{array}$ & $\begin{array}{c}-0.503 * * * \\
(0.171)\end{array}$ & $\begin{array}{c}-0.481 * * * \\
(0.173)\end{array}$ & $\begin{array}{c}-0.653 * * * \\
(0.225)\end{array}$ & $\begin{array}{l}-0.281 \\
(0.259)\end{array}$ \\
\hline Ln distcap & $\begin{array}{l}0.00465 \\
(0.0384)\end{array}$ & $\begin{array}{c}0.226 * * * \\
(0.0522)\end{array}$ & $\begin{array}{c}0.0352 \\
(0.0410)\end{array}$ & $\begin{array}{c}0.229 * * * \\
(0.0513)\end{array}$ & $\begin{array}{c}0.337 * * * \\
(0.0730)\end{array}$ & $\begin{array}{l}0.148 * * \\
(0.0638)\end{array}$ \\
\hline Landlocked_ij & $\begin{array}{l}-0.131 * \\
(0.0704)\end{array}$ & $\begin{array}{c}0.0551 \\
(0.0750)\end{array}$ & $\begin{array}{c}-0.142 * * \\
(0.0693)\end{array}$ & $\begin{array}{c}0.0390 \\
(0.0752)\end{array}$ & $\begin{array}{l}-0.111 \\
(0.110)\end{array}$ & $\begin{array}{c}-0.0286 \\
(0.0962)\end{array}$ \\
\hline Colony & $\begin{array}{c}0.203 * * \\
(0.104)\end{array}$ & $\begin{array}{l}-0.0267 \\
(0.111)\end{array}$ & $\begin{array}{l}0.0775 \\
(0.109)\end{array}$ & $\begin{array}{l}-0.0871 \\
(0.112)\end{array}$ & $\begin{array}{l}-0.170 \\
(0.133)\end{array}$ & $\begin{array}{c}-0.00945 \\
(0.156)\end{array}$ \\
\hline Comlang & $\begin{array}{c}-0.341 * * * \\
(0.0819)\end{array}$ & $\begin{array}{c}-0.222 * * * \\
(0.0818)\end{array}$ & $\begin{array}{c}-0.350 * * * \\
(0.0808)\end{array}$ & $\begin{array}{c}-0.222 * * * \\
(0.0825)\end{array}$ & $\begin{array}{l}-0.211 * \\
(0.113)\end{array}$ & $\begin{array}{l}-0.0506 \\
(0.109)\end{array}$ \\
\hline Contig & $\begin{array}{l}-0.0456 \\
(0.127) \\
\end{array}$ & $\begin{array}{c}-0.263 * * \\
(0.133) \\
\end{array}$ & $\begin{array}{l}-0.208 \\
(0.128) \\
\end{array}$ & $\begin{array}{c}-0.376^{* * * *} \\
(0.131) \\
\end{array}$ & $\begin{array}{c}-0.361 * * \\
(0.172)\end{array}$ & $\begin{array}{l}-0.264 \\
(0.161) \\
\end{array}$ \\
\hline Polity2ip_i & $\begin{array}{c}-0.0125 \\
(0.0104) \\
-\end{array}$ & $\begin{array}{l}-0.00683 \\
(0.0104)\end{array}$ & $\begin{array}{l}-0.00163 \\
(0.0106)\end{array}$ & $\begin{array}{l}2.59 \mathrm{e}-05 \\
(0.0106)\end{array}$ & $\begin{array}{c}0.0204 \\
(0.0138)\end{array}$ & $\begin{array}{l}-0.0160 \\
(0.0153)\end{array}$ \\
\hline Polity2ip_j & $\begin{array}{c}0.0285 * * * \\
(0.00783)\end{array}$ & $\begin{array}{c}-0.0123 \\
(0.00829)\end{array}$ & $\begin{array}{c}-0.0207 * * * \\
(0.00764)\end{array}$ & $\begin{array}{l}-0.00809 \\
(0.00799)\end{array}$ & $\begin{array}{c}0.0151 * \\
(0.00893)\end{array}$ & $\begin{array}{r}-0.00877 \\
(0.0120)\end{array}$ \\
\hline Poldif_ij & $\begin{array}{c}-0.0178 * * \\
(0.00766)\end{array}$ & $\begin{array}{c}0.00267 \\
(0.00835)\end{array}$ & $\begin{array}{l}-0.0125^{*} \\
(0.00740)\end{array}$ & $\begin{array}{c}0.00633 \\
(0.00817)\end{array}$ & $\begin{array}{c}0.0282 * * * \\
(0.00959)\end{array}$ & $\begin{array}{l}0.00433 \\
(0.0124)\end{array}$ \\
\hline AgreeUN_US_i & $\begin{array}{c}0.331 \\
(0.334)\end{array}$ & $\begin{array}{c}-1.487 * * * \\
(0.490)\end{array}$ & $\begin{array}{l}-0.409 \\
(0.381)\end{array}$ & $\begin{array}{c}-1.961 * * * \\
(0.498)\end{array}$ & $\begin{array}{c}-2.493 * * * \\
(0.661)\end{array}$ & $\begin{array}{l}-0.509 \\
(0.728)\end{array}$ \\
\hline AgreeUN_US_j & $\begin{array}{l}0.0444 \\
(0.374)\end{array}$ & $\begin{array}{c}0.493 \\
(0.392)\end{array}$ & $\begin{array}{l}-0.157 \\
(0.369)\end{array}$ & $\begin{array}{c}0.385 \\
(0.392)\end{array}$ & $\begin{array}{c}0.566 \\
(0.453)\end{array}$ & $\begin{array}{c}0.540 \\
(0.499)\end{array}$ \\
\hline AgreeUN_ij & $\begin{array}{c}0.713 * * \\
(0.305)\end{array}$ & $\begin{array}{c}0.366 \\
(0.316)\end{array}$ & $\begin{array}{c}0.852 * * * \\
(0.307)\end{array}$ & $\begin{array}{c}0.473 \\
(0.318)\end{array}$ & $\begin{array}{l}0.0153 \\
(0.385)\end{array}$ & $\begin{array}{c}1.690 * * * \\
(0.510)\end{array}$ \\
\hline Conflict last 2 years $\mathrm{j}$ & $\begin{array}{l}0.113 * * \\
(0.0542)\end{array}$ & $\begin{array}{l}-0.125 * \\
(0.0666)\end{array}$ & $\begin{array}{l}0.00764 \\
(0.0582)\end{array}$ & $\begin{array}{c}-0.194 * * * \\
(0.0671)\end{array}$ & $\begin{array}{c}-0.221 * * \\
(0.0868)\end{array}$ & $\begin{array}{l}-0.203 * \\
(0.105)\end{array}$ \\
\hline Military pact & $\begin{array}{c}0.374 * * * \\
(0.0863) \\
\end{array}$ & $\begin{array}{c}0.0776 \\
(0.0955) \\
\end{array}$ & $\begin{array}{c}0.182 * \\
(0.0943) \\
\end{array}$ & $\begin{array}{l}-0.0663 \\
(0.0997) \\
\end{array}$ & $\begin{array}{r}-0.0745 \\
(0.136) \\
\end{array}$ & $\begin{array}{l}-0.137 \\
(0.136) \\
\end{array}$ \\
\hline Inverse Mills Ratio & & $\begin{array}{c}-1.370 * * * \\
(0.230)\end{array}$ & & $\begin{array}{c}-1.345^{* * * *} \\
(0.239)\end{array}$ & $\begin{array}{c}-1.598 * * * \\
(0.377)\end{array}$ & $\begin{array}{c}-0.741 * * \\
(0.305)\end{array}$ \\
\hline Z Hat & & & $\begin{array}{c}0.208 * * * \\
(0.0445)\end{array}$ & $\begin{array}{c}0.192 * * * \\
(0.0437)\end{array}$ & $\begin{array}{c}0.260 * * * \\
(0.0523)\end{array}$ & $\begin{array}{c}0.178 * * * \\
(0.0481)\end{array}$ \\
\hline $\mathrm{Z} \mathrm{Hat}^{2}$ & & & $\begin{array}{c}0.0120 * * * \\
(0.00285)\end{array}$ & $\begin{array}{l}0.0126 * * * \\
(0.00284)\end{array}$ & $\begin{array}{l}0.0155 * * * \\
(0.00302)\end{array}$ & $\begin{array}{c}0.0119 * * * \\
(0.00354)\end{array}$ \\
\hline $\mathrm{Z} \mathrm{Hat}^{3}$ & & & $\begin{array}{c}0.000230 * * * \\
(6.21 \mathrm{e}-05)\end{array}$ & $\begin{array}{c}0.000255 * * * \\
(6.37 \mathrm{e}-05)\end{array}$ & $\begin{array}{c}0.000288 * * * \\
(6.24 \mathrm{e}-05)\end{array}$ & $\begin{array}{c}0.000250 * * * \\
(8.81 \mathrm{e}-05)\end{array}$ \\
\hline Observations & 12,699 & 12,699 & 12,699 & 12,699 & 7,639 & 5,060 \\
\hline Number of pairs & 1,729 & 1,729 & 1,729 & 1,729 & 1,028 & 1,205 \\
\hline $\mathrm{R}^{2}$ Overall & 0.226 & 0.239 & 0.251 & 0.264 & 0.322 & 0.214 \\
\hline
\end{tabular}

Notes: Robust standard errors in parentheses are clustered at the country-pair level. *** $\mathrm{p}<0.01, * * \mathrm{p}<0.05$, * $\mathrm{p}<0.1$.Estimation method: Mundlak approach for panel data (Probit random effects model including the averages of the time-variant variables, which coefficients are not reported to save space). 
Table 3. Determinants of Goods Exports

\begin{tabular}{|c|c|c|c|c|}
\hline IND. VAR.: & Trade in Arms $(1 / 0)$ & Trade in Goods $(1 / 0)$ & Ln Trade in Arms & Ln Trade in Goods \\
\hline Period: 1962-2007 & (1) & (2) & (3) & (4) \\
\hline VARIABLES & Logit & Logit & $2^{\text {nd }}$ step HMR & $2^{\text {nd }}$ step HMR \\
\hline \multirow[t]{2}{*}{ Ln GDP_i } & $0.590 * * *$ & $-0.299 * * *$ & $0.397 *$ & $1.897 * * *$ \\
\hline & $(0.0718)$ & $(0.0469)$ & $(0.238)$ & $(0.0673)$ \\
\hline \multirow[t]{2}{*}{$\operatorname{Ln~GDP}_{3}$} & 0.0281 & 0.0510 & $0.773 * * *$ & $1.753 * * *$ \\
\hline & $(0.0617)$ & $(0.0574)$ & $(0.206)$ & $(0.0618)$ \\
\hline \multirow[t]{2}{*}{ Ln GDPpc_i } & $-0.485 * * *$ & $0.873 * * *$ & $-0.797 * * *$ & -0.0690 \\
\hline & $(0.0713)$ & $(0.0422)$ & $(0.245)$ & $(0.0677)$ \\
\hline \multirow[t]{2}{*}{ Ln GDPpc_j } & $0.216 * * *$ & $0.109 * *$ & $-0.481 * * *$ & $-0.582 * * *$ \\
\hline & $(0.0547)$ & $(0.0475)$ & $(0.173)$ & $(0.0553)$ \\
\hline \multirow[t]{2}{*}{ Ln distcap } & $-0.165 * * *$ & $-0.379 * * *$ & $0.229 * * *$ & $-1.428 * * *$ \\
\hline & $(0.0252)$ & $(0.0182)$ & $(0.0513)$ & $(0.0266)$ \\
\hline \multirow[t]{2}{*}{ Landlocked_ij } & 0.305 & $-0.657 * * *$ & 0.0390 & $-0.489 * * *$ \\
\hline & $(0.310)$ & $(0.128)$ & $(0.0752)$ & $(0.0379)$ \\
\hline \multirow[t]{2}{*}{ Colony } & $0.457^{* * *}$ & $0.207^{* *}$ & -0.0871 & $1.207 * * *$ \\
\hline & $(0.0517)$ & $(0.0846)$ & $(0.112)$ & $(0.135)$ \\
\hline \multirow[t]{2}{*}{ Comlang } & $0.0813^{*}$ & $0.261 * * *$ & $-0.222 * * *$ & $0.909 * * *$ \\
\hline & $(0.0462)$ & $(0.0292)$ & $(0.0825)$ & $(0.0614)$ \\
\hline \multirow[t]{2}{*}{ Contig } & 0.0878 & -0.0988 & $-0.376 * * *$ & $0.592 * * *$ \\
\hline & $(0.0694)$ & $(0.0761)$ & $(0.131)$ & $(0.124)$ \\
\hline \multirow[t]{2}{*}{ Polity2ip_i } & $0.0240 * * *$ & $0.00558 * * *$ & $2.59 \mathrm{e}-05$ & $0.0473 * * *$ \\
\hline & $(0.00362)$ & $(0.00126)$ & $(0.0106)$ & $(0.00312)$ \\
\hline \multirow{2}{*}{ Polity2ip_j } & $-0.0229 * * *$ & $0.00392 * * *$ & -0.00809 & $0.00609 * * *$ \\
\hline & $(0.00298)$ & $(0.00138)$ & $(0.00799)$ & $(0.00213)$ \\
\hline \multirow[t]{2}{*}{ Poldif_ij } & $-0.0234 * * *$ & $-0.00553 * * *$ & 0.00633 & $0.00394 * *$ \\
\hline & $(0.00260)$ & $(0.00101)$ & $(0.00817)$ & $(0.00181)$ \\
\hline \multirow[t]{2}{*}{ AgreeUN_US_i } & 0.00450 & $1.143^{* * *}$ & $-1.961 * * *$ & $-0.523 * * *$ \\
\hline & $(0.112)$ & $(0.0792)$ & $(0.498)$ & $(0.0985)$ \\
\hline \multirow[t]{2}{*}{ AgreeUN_US_j } & -0.0731 & $0.265^{* * *}$ & 0.385 & -0.0674 \\
\hline & $(0.127)$ & $(0.0661)$ & $(0.392)$ & $(0.0978)$ \\
\hline \multirow[t]{2}{*}{ AgreeUN_ij } & 0.0698 & 0.0364 & 0.473 & $1.037 * * *$ \\
\hline & (0.0519) & $(0.0276)$ & $(0.318)$ & $(0.102)$ \\
\hline \multirow[t]{2}{*}{ Conflict last 2 years_ $\mathrm{j}$} & $0.178 * * *$ & $0.0416 * * *$ & $-0.194 * * *$ & $-0.0617 * * *$ \\
\hline & $(0.0247)$ & $(0.0145)$ & $(0.0671)$ & $(0.0182)$ \\
\hline \multirow[t]{2}{*}{ Military pact } & $0.530 * * *$ & $0.443 * * *$ & -0.0663 & $0.458 * * *$ \\
\hline & $(0.0463)$ & $(0.0416)$ & $(0.0997)$ & $(0.0534)$ \\
\hline \multirow[t]{2}{*}{ Mandatory Embargo } & $-0.558 * * *$ & $-0.428 * * *$ & & \\
\hline & $(0.155)$ & $(0.0596)$ & & \\
\hline \multirow[t]{2}{*}{ Inverse Mills Ratio } & & & $-1.345^{* * *}$ & $1.082 * * *$ \\
\hline & & & $(0.239)$ & $(0.108)$ \\
\hline \multirow[t]{2}{*}{ Z Hat } & & & $0.192 * * *$ & -0.00484 \\
\hline & & & $(0.0437)$ & $(0.00534)$ \\
\hline \multirow[t]{2}{*}{$\mathrm{Z} \mathrm{Hat}^{2}$} & & & $0.0126 * * *$ & $0.00130 * * *$ \\
\hline & & & $(0.00284)$ & $(0.000193)$ \\
\hline \multirow[t]{2}{*}{$\mathrm{Z} \mathrm{Hat}^{3}$} & & & $0.000255 * * *$ & $-2.44 \mathrm{e}-05 * * *$ \\
\hline & & & $(6.37 \mathrm{e}-05)$ & $(2.58 \mathrm{e}-06)$ \\
\hline Observations & 477,961 & 479,021 & 12,699 & 285,374 \\
\hline Number of pairs & 15,255 & 14,387 & 1,729 & 13,354 \\
\hline Pseudo R ${ }^{2}$ (Overall) & 0.421 & 0.325 & 0.264 & 0.592 \\
\hline
\end{tabular}

Note: Robust standard errors in parentheses are clustered at the country-pair level. ${ }^{* * *} \mathrm{p}<0.01,{ }^{*} \mathrm{p}<0.05,{ }^{*} \mathrm{p}<0.1$. 
Figures

Figure 1: Political Dimensions

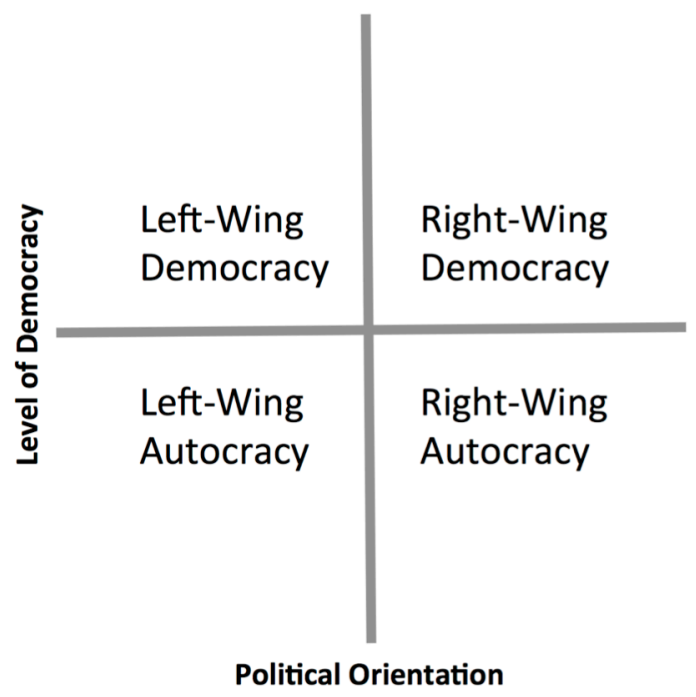


Figure 2: Political Orientation and Level of Democracy in Single Years

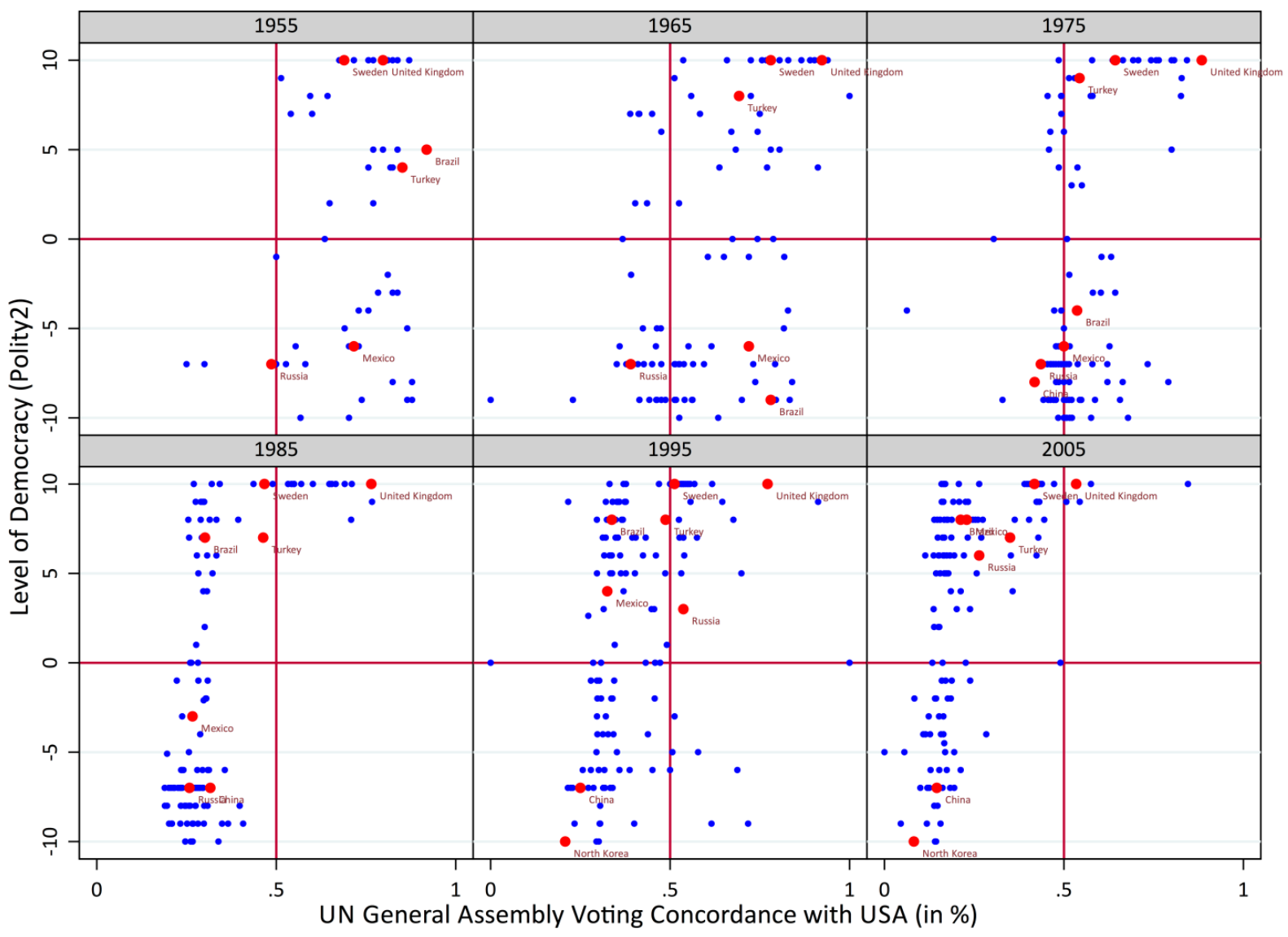

Notes: Markers indicate countries. The red markers show a few countries as examples tracked over time; the figure shows countries that were members of the UN and participated in the voting of the UN General Assembly. 
Figure 3. Most important exporters (export shares in \%)

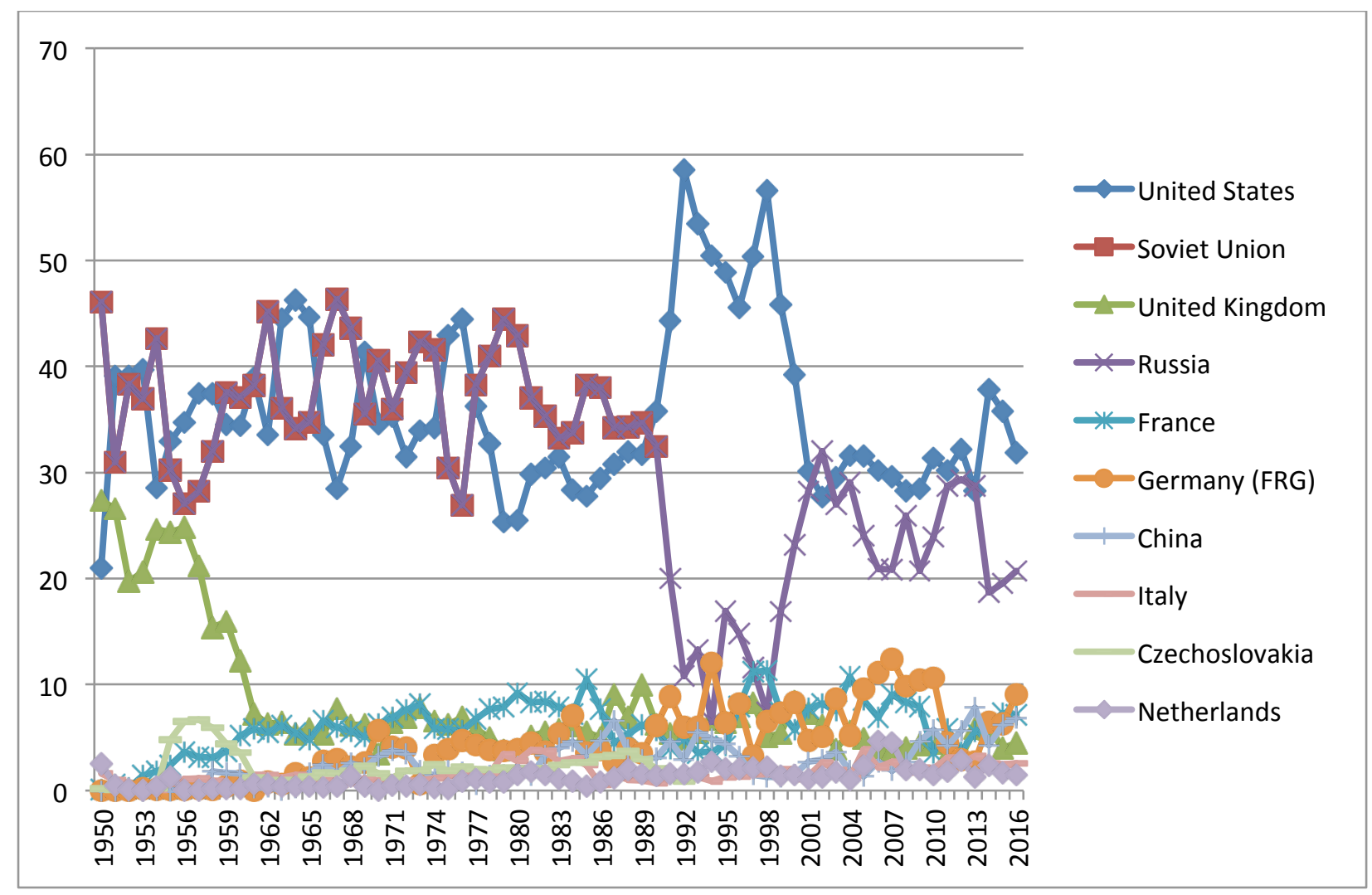

Source: SIPRI. 
Figure 4. Amount traded in million USD

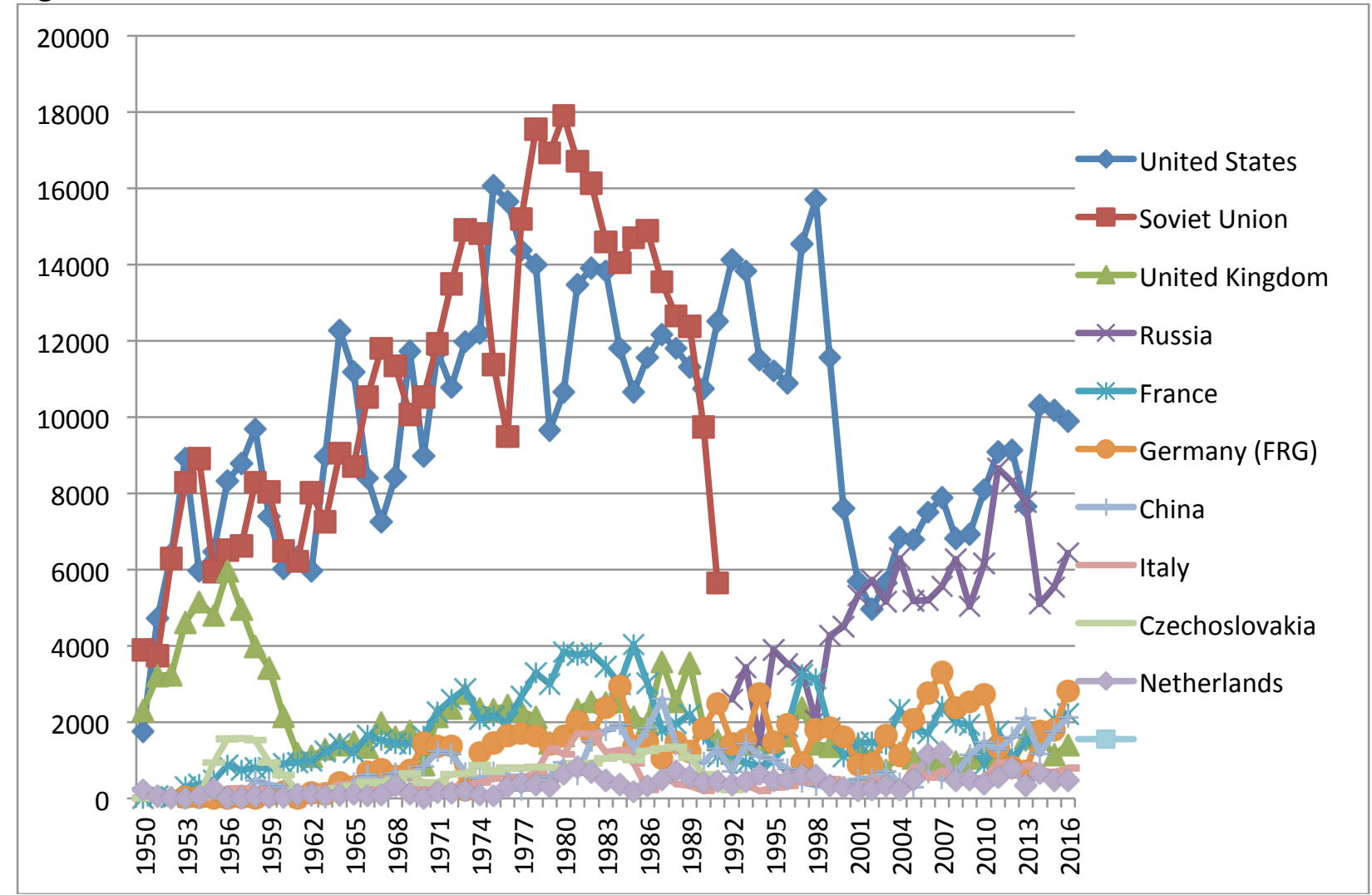

Source: SIPRI. 
Figure 5.Total exports of MCW in USD

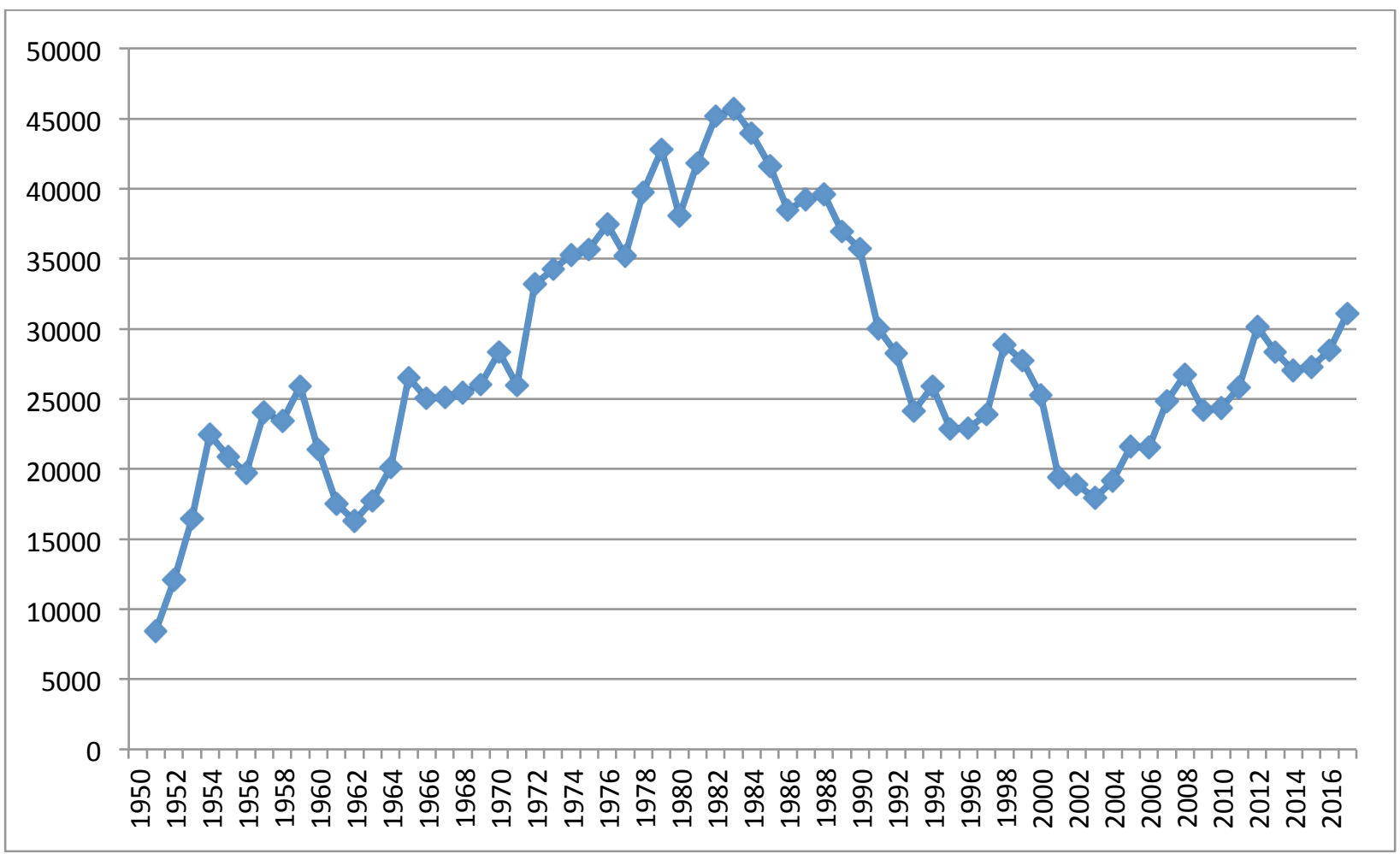

Source: SIPRI. 